\title{
Ancient Cities and Landscapes in the Kurdistan Region of Iraq: The Erbil Plain Archaeological Survey 2012 Season
}

\section{Citation}

Ur, Jason, Lidewijde de Jong, Jessica Giraud, James F. Osborne, and John MacGinnis. 2013. Ancient cities and landscapes in the Kurdistan region of Iraq: The Erbil Plain Archaeological Survey 2012 season. Iraq 75:89-118.

\section{Permanent link}

http://nrs.harvard.edu/urn-3:HUL.InstRepos:11510264

\section{Terms of Use}

This article was downloaded from Harvard University's DASH repository, and is made available under the terms and conditions applicable to Other Posted Material, as set forth at http:// nrs.harvard.edu/urn-3:HUL.InstRepos:dash.current.terms-of-use\#LAA

\section{Share Your Story}

The Harvard community has made this article openly available. Please share how this access benefits you. Submit a story.

Accessibility 


\title{
ANCIENT CITIES AND LANDSCAPES IN THE KURDISTAN REGION OF IRAQ: THE ERBIL PLAIN ARCHAEOLOGICAL SURVEY 2012 SEASON $^{1}$
}

\author{
By JASON UR, LIDEWIJDE DE JONG, JESSICA GIRAUD, JAMES F. OSBORNE AND JOHN MACGINNIS
}

In 2012, the Erbil Plain Archaeological Survey (EPAS) conducted its first season of fieldwork. The project's goal is the complete mapping of the archaeological landscape of Erbil, with an emphasis on the Neo-Assyrian and Hellenistic periods. It will test the hypothesis that the Neo-Assyrian landscape was closely planned. This first report emphasizes the project's field methodology, especially the use of a variety of satellite remote sensing imagery. Our preliminary results suggest that the plain was part of the urbanized world of Mesopotamia, with new cities of the Bronze Age, Iron Age, and Sasanian era identified.

\section{Introduction}

Iraq is one of the intellectual birthplaces of the study of ancient settlement patterns and landscapes. Yet in the last forty years, innovative research in the Near East has taken place exclusively in adjacent regions, largely for political reasons internal to the Republic of Iraq. Even during the "Golden Age" of archaeological survey in Iraq in the 1960s and 1970s, research was limited to the southern plains, the heartland of Sumero-Akkadian civilization. Foreign survey was forbidden in the northern part of the country, including the three governorates of the Kurdistan Region. Until recently, our understanding of the archaeological heritage of northern Iraq has been restricted primarily to the monumental remains discovered by early excavations at the region's largest sites. As a result, the state of research on ancient Assyria is radically skewed: our discipline has extraordinary knowledge of the highest ranks of the elites, but near-complete ignorance of the rest of society. For other stages of northern Mesopotamian history, the shortcomings are even more extreme.

After a two-decade hiatus in foreign fieldwork, an opportunity to balance the dataset for north Mesopotamian settlement and landscape has presented itself. Since 2009, political violence has declined dramatically throughout the country, especially in the Kurdistan Region. The State Board of Antiquities and Heritage (SBAH) in Baghdad and the General Directorate of Antiquities of the Kurdistan Regional Government have expressed a new openness to foreign research. In this new political climate, the authors initiated an archaeological survey project in the summer of $2012 .^{2}$ In this initial report, we focus on our methods, especially the use of remote sensing datasets, and preliminary results on the settlement and off-site landscapes, based on both remote sensing analysis and field survey.

\footnotetext{
${ }^{1}$ The project would not have been possible without the permission and encouragement of our colleagues in the General Directorate of Antiquities for the KRG (directed by Abubakir Zainaddin [Mala Awat]), the Erbil Directorate of Antiquities (directed by Haydar Hussein), and the State Board of Antiquities and Heritage in Baghdad (especially its former director Qais Rashid). We are thankful for the logistical help of the KRG's Representation in Washington DC, especially its Director of Culture and Community, Najat Abdullah.

EPAS benefited greatly from the advice, collegiality, and intellectual stimulation of our new academic colleagues in the Kurdistan Region, especially Olivier Rouault and Maria Grazia Masetti-Rouault (Qasr Shemamok excavations), Konstantinos Kopanias (Tell Nader and Tell Baqrta excavations), Daniele Morandi Bonacossi (Land of Nineveh Regional Project), Rafal Kolinski (Upper Greater Zab Archaeological Reconnaissance), and Karel Nováček (Czech Archaeological Mission to Erbil). We owe a special
}

debt to David Michelmore (Principal of the Consultancy for Conservation) and Jessica Johnson (Academic Director of the Iraqi Institute for the Conservation of Antiquities and Heritage) for hosting the team members and introducing us to Erbil society.

Funding for the 2012 EPAS field season was provided by Harvard University, the American School of Prehistoric Research, and the University of Groningen.

This manuscript benefited from references and critical comments by Daniele Morandi Bonacossi, Maria Grazia Masetti-Rouault, Olivier Rouault, and Karel Nováček.

${ }^{2}$ The 2012 EPAS academic team consisted of project director Jason Ur (Harvard University); associate directors Lidewijde de Jong (Groningen University), Jessica Giraud (IFPO Iraq), and James Osborne (Johns Hopkins University); graduate student Max Price (Harvard University); and Erbil Directorate of Antiquities representatives Khalil Barzanji and Gareb Bawamurad. Our driver, translator, and unfailingly joyful companion was Bapir Rashid Bawel. 


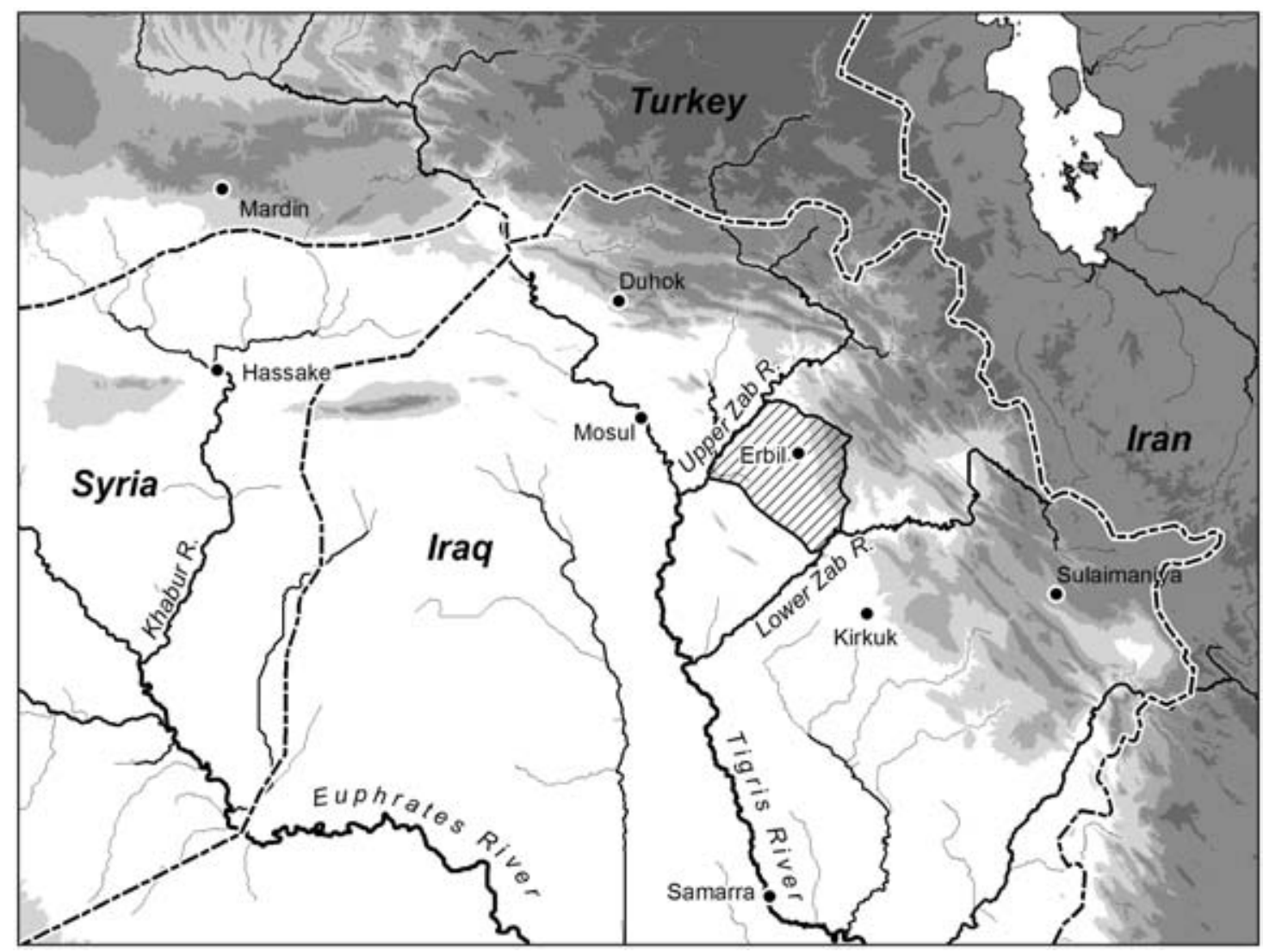

Fig. 1 Geographical location of the Erbil Plain Archaeological Survey (EPAS) in the Kurdistan Region of northern Iraq.

\section{Erbil Plain Archaeological Survey (EPAS) project goals}

The Erbil Plain Archaeological Survey (EPAS) encompasses 3,200 $\mathrm{km}^{2}$ in the centre of Erbil Governorate (Fig. 1). This region was chosen because it includes large parts of two ancient Assyrian provinces, Arbail and Kilizu, including their eponymous capital cities (now Erbil and Qasr Shemamok, respectively). The nature of the Neo-Assyrian landscape is the primary avenue of investigation of the project. Fragmentary but compelling archaeological evidence collected since the time of Layard suggests that the Neo-Assyrian kings carefully planned the landscape of the imperial core and went to great lengths to realize their vision (for a recent review, see Ur in press). The most visible aspect of this design is the sequence of new capital cities, which are well known archaeologically (at least their elite quarters; see most recently Pedde 2012). Royal inscriptions and letters reveal the close interest of the king himself (e.g., Sargon at Khorsabad; Parpola 1995). The kings, especially Ashurnasirpal II and Sennacherib, and their engineers also redirected the surface hydrology of rivers and wadis into canals that fed cities and countryside alike. These canal systems and associated reliefs have been studied anecdotally on the ground (Bachmann 1927, Jacobsen and Lloyd 1935, Oates 1968, Reade 1978, 2002, Boehmer 1997), exhaustively via texts (Bagg 2000), and most recently from the perspective of historical aerial photographs and satellite imagery (Ur 2005, Altaweel 2008).

The most enigmatic element of the Neo-Assyrian landscape is the possible deliberate colonization of the countryside via forced immigration of conquered peoples. Royal inscriptions invoke this process frequently, and make it clear that the primary destinations of deportees were Assyrian cities and their rural hinterlands (Oded 1979). In adjacent regions, the Iron Age landscape was evenly settled by small, presumably agricultural villages, a pattern that could be interpreted as the signature of a planned agricultural colonization (Morandi Bonacossi 2000, Wilkinson 1995, Wilkinson and Barbanes 2000, Wilkinson et al. 2005, Parker 2001, Matney 2010). This pattern has been found 
throughout the Jazira, on the western edges of the imperial core, but it has yet to be demonstrated in the Assyrian heartland. These three elements (planned cities, engineered hydrology, and rural colonization) combine to suggest a highly structured and planned landscape, and constitute the primary settlement model to be tested by EPAS.

The survey will, however, investigate settlement and landscape for all periods of human sedentary occupation, from the Neolithic to the present. For example, the Early Bronze Age (third millennium B.C.) was a time of extensive urbanization in surrounding areas of northern Mesopotamia, stretching in an arc from the Sinjar plain, across the Khabur basin, the Harran plain, Sajur Valley, and into western Syria (Stein 2004, Ur 2010a, Matney 2012). In contrast to the hypothesized planned landscape of the Neo-Assyrian period, the highly structured EBA landscape was largely emergent from the actions of individual households, both large and small (Ur 2009, in press). The Erbil plain is a geographical extension of this urban arc, and also falls on the interface between the northern and southern Mesopotamian worlds; the question of whether it participated in this earlier urban phase is an important one.

Another avenue of research, closely related to the Assyrian case, is the nature of the post-Assyrian landscape, and particularly how the Erbil plain fits into the larger Hellenistic and Parthian-Roman world. The establishment of colonies by Alexander and his Seleucid successors and the creation of two new capital centres, at Antioch on the Orontes and Seleucia on the Tigris, represent two major changes in the character of urbanization. Colonization was not restricted to the towns but also spread to the surrounding countryside, where newcomers tilled the land. A contingent of GreekMacedonian colonists likely settled at Nineveh (Oates 1968), but little else is known about the impact of the arrival of new settlers in northern Iraq and the Erbil plain. Studies of other Hellenistic kingdoms suggest divergent patterns in rural settlements, farming practices, and demography, with strong regional variation in prosperity and decline (for instance, Alcock 1994). Whereas the urban picture illustrates the integration of local communities into regional networks, the countryside highlights the mixed responses to the new economic and social reality of the Hellenistic world. The question of how the former Assyrian core responded to its new position in the Seleucid empire will be a central focus of research.

With the conquest of the Erbil plain by Parthian armies in the mid-second century B.C. and the creation of the Roman province of Syria in mid-first century B.C., the Erbil plain was drawn into border politics. Roman armies advanced into North Mesopotamia and dozens of military sites have been identified between the Khabur river and the Jebel Sinjar, and along the Tigris down to the Upper Zab, where a small castellum was located at Jaddalah (Oates 1956, Oates and Oates 1959, Kennedy and Riley 1990). With Parthian client kings residing in Arbela and Roman soldiers across the Tigris, the Erbil plain was the heart of contested land of two powerful empires. In Syria, the Roman military modified local landscapes by paving main roads, constructing hydraulic installations, and placing new demands on local resources (e.g., de Jong 2011). The impact of the border location on settlement and demographic patterns away from the camps, however, remains unexplored for northern Iraq.

By its nature, landscape archaeology must consider all time periods, and EPAS emphasizes the evolution of land use in all past times via close studies of the "off-site" landscape (Wilkinson 2003). Of particular interest are the agricultural systems that sustained village-level and urban settlements. The Erbil plain is a palimpsest of multiple overlapping irrigation landscapes, ranging from massive state-created open canals to small-scale karez (qanat) systems sustaining a single village; their remains can be documented prior to fieldwork via CORONA satellite photographs (described below). In neighboring regions, EBA dry-farming systems were enhanced with manuring using settlement-based debris (Wilkinson 1989, 2003: 117-18). Finally, the vivid landscapes of movement documented in the Jazira (Wilkinson 1993, 2003, Ur 2003, 2010b) appears to have continued into the Erbil plain and adjacent regions (Altaweel 2003, 2008), but has yet to be ground-truthed. These landscape elements must be synthesized with settlement patterns in order to produce a more vibrant picture of evolving cultural landscapes.

EPAS has two important and interrelated non-academic goals. First, it will involve Iraqis of all backgrounds. Historically, archaeological training in Iraq has emphasized excavation field techniques, and has not included formal training in GIS, remote sensing, and other digital 
technologies. Furthermore, the project will result in an inventory of historically significant places, to be made available in a timely manner to decision makers in the Directorates of Antiquities and beyond, so that informed choices can be made regarding the protection or salvaging of threatened sites. These two goals must be placed side by side; Iraq is too large, and the pace of development too rapid, for complete inventories to be compiled solely by foreign academic missions. The development threats to the ancient landscapes of the Erbil region, detailed below, are especially dire.

In addition to these long-term project goals, EPAS had several immediate priorities for the 2012 field season: to confirm the effectiveness of our CORONA-based site identification methodology; develop a field survey method suitable for the physical and cultural environment of the Erbil plain; and conduct intensive field survey in several circumscribed regions of the survey area. The project achieved these short-term goals, and also made some initial attempts at addressing larger questions of settlement and land use history.

\section{Previous landscape research in northern Iraq}

Ancient landscapes, especially sites and rock-cut monuments, are by no means unknown in northern Iraq, but have not been subjected to systematic scrutiny (recently reviewed in Ur in press). Early observations by Layard (e.g., 1853) and other explorers were often detailed, although frequently saddled with flawed interpretations and presented as travel narratives describing day trips away from excavation-based research in the great cities. Felix Jones" "Vestiges of Assyria" map series (1855) is a major exception, and unfortunately limited to the Tigris valley. Observations became more systematic in the twentieth century, with Bachmann's survey of Assyrian rock reliefs (1927), the mapping of Sennacherib's Khinis canal to Nineveh (Jacobsen and Lloyd 1935), and early aerial investigations by Aurel Stein (Gregory and Kennedy 1985). Pioneering synthetic studies by David Oates (1968) and Julian Reade $(1978,2002)$ took major interpretive steps, but were unfortunately undertaken just before foreign research became impossible in the Kurdistan Region.

Intensive studies of the settlement landscape have lagged far behind research on the monumental and irrigation landscapes. Several reconnaissances investigated the Sinjar plain (Lloyd 1938, Reade 1968) and the Wadi Tharthar (Ibrahim 1986), but at low intensity. In the Tigris Valley, the few surveys undertaken have been in advance of dam construction (Mühl and Sulaiman 2011). The era of extensive site surveys in southern Iraq never expanded to the north.

On the other hand, the availability of historical satellite imagery has inspired a range of recent remote sensing studies. Many have taken advantage of CORONA intelligence satellite photographs to investigate urban form (Scardozzi 2011, Ur 2013b), inter-site routes of communication (Altaweel 2003, 2008, Mühl 2012), and canal systems (Ur 2005, Altaweel 2008). With one exception (Altaweel 2005), Assyrian landscape studies have yet to employ multispectral systems, although such methods have been successful in alluvial landscapes elsewhere in northern Mesopotamia (e.g., Menze and Ur 2012).

This situation is poised to change rapidly. In the past years, several new landscape projects have been initiated. The focus has been on the eastern periphery of Assyria, in the governorate of Suleimaniya (e.g., Mühl 2010, Altaweel et al. 2012), but new surveys were initiated in 2012 in Garmiyan (the Sirwan Regional Project, directed by Emre Şerifoğlu, Claudia Glatz, and Jesse Casana), Dohuk and Erbil governorates (the Land of Nineveh Regional Project, directed by Daniele Morandi Bonacossi, and the Upper Zab Archaeological Reconnaissance, directed by Rafał Koliński), and Suleimaniya (the French Archaeological Mission in Suleimaniya Governorate, directed by Jessica Giraud).

\section{Physical geography of the Erbil Plain}

The EPAS survey region was defined by geographical features (Figure 2). To the north-west, it is bounded by the Upper Zab, and by the Lower Zab at Altın Köprü at its southern point. The southwestern limit is the first long anticlinal hill that separates the Erbil Plain from the Makhmur Plain. The north-eastern limit is the valley of the Chai Bastora. The watershed between the Erbil Plain and the valley of the Shalgha River defines the eastern survey boundary. The project area is thus geographically diverse, containing a range of river valleys, flat alluvial plains, rolling gravel hills, and Zagros foothill zones. 


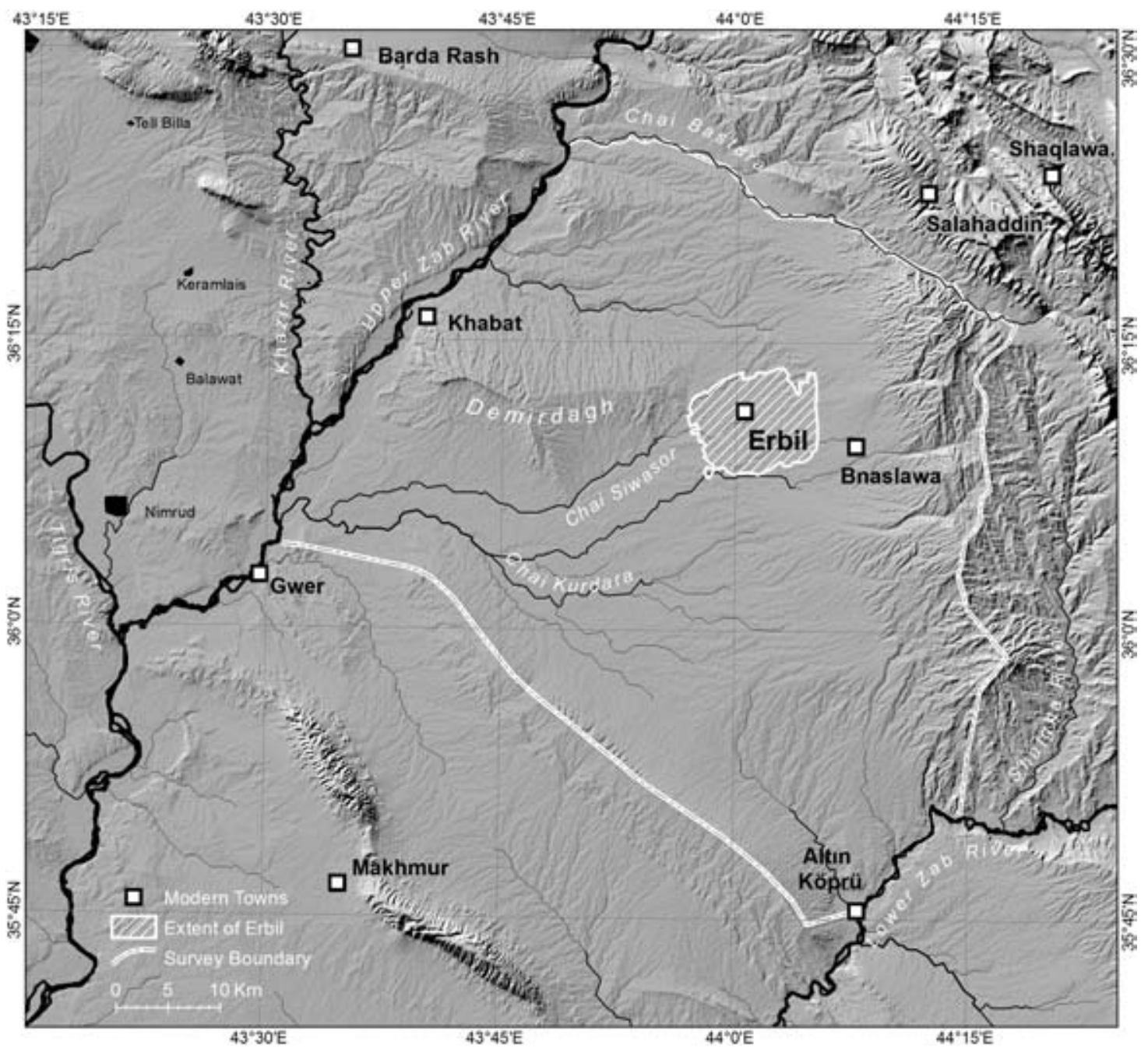

Fig. 2 The physical geography of the Erbil Plain.

The Erbil plain has cool wet winters and hot dry summers. It receives substantial rainfall on average, enough to support dry-farming agriculture without irrigation in most years (Buringh 1960: 42-44). Erbil itself gets $500 \mathrm{~mm} / \mathrm{year}$ of rainfall; the plain to its north toward Shaqlawa receives slightly more, and the southwestern plain toward Makhmur receives slightly less. These figures are averages, and can show dramatic inter-annual variability. The terrain is generally undulating to rolling, with the exception of the plain of the Chai Siwasor, stretching from Erbil to the Upper Zab, which is nearly flat. Deep brown soils over Bakhtiari gravels cover most of the plain, with thinner brown soils on the slopes of the hills; erosion is negligible (Buringh 1960:218-22). Most of the region drains into the Upper Zab, via the Chai Bastora to the north, or via the Chai Siwasor or Chai Kurdara below Erbil; the southern end of the region drains into the Lower Zab. All of the major drainages, and many of the smaller ones, were perennial in the mid-twentieth century; today only the Chai Siwasor flows year-round, because it acts as the outflow for wastewater from the city of Erbil. The region falls into Guest's moist-steppe zone, which is characterized by extensive grasses and herbs, with some traces of semi-woody or herbaceous vegetation that has survived the millennia of cultivation (Guest 1966: 71-72).

EPAS survey methodology

In this initial report, we describe in some detail the project's survey methodology. Compared to surveys in the New World and the Mediterranean, publications of Near Eastern surveys have not 
been explicit about how methodological decisions were made (e.g., survey boundaries, sampling versus full coverage, intensity of coverage, site definition) nor have they shown much introspection on how those decisions impacted interpretation. We therefore include a substantial methodological overview in this section, with an initial critical assessment in the results section below.

Remote sensing and other geospatial datasets. EPAS is heavily reliant on satellite remote sensing for site and landscape feature identification. This situation is necessitated in part by the broad scale of the survey region, which could not be treated fully by purely pedestrian (or even vehicular) methods. More significantly, it stems from the remarkable power of CORONA intelligence satellite photographs to resolve archaeological remains. Since declassification (1995) and public availability (1998), CORONA imagery has been used extensively across the Near East (see reviews in Fowler 2004, 2013, Challis 2007, Ur 2013a). In similar environments in the adjacent northern Mesopotamian plains of Syria, CORONA has been particularly effective in site and landscape feature identification (Ur 2003, 2010b), and has already been employed to investigate Assyrian irrigation (Ur 2005, Altaweel 2008, Mühl 2012).

In advance of field survey, the project compiled a geodatabase of settlement sites and landscape features identified subjectively using five CORONA missions. CORONA imagery is highly variable across missions, which capture the landscape at different seasons, under fluctuating vegetation and soil moisture conditions, and under different types of land use. From extensive analysis of the Upper Khabur basin via CORONA (Ur 2010b: 43-46), it became clear that the most significant variable was soil moisture, which is also the case on the Erbil Plain. The two August missions (1036 and 1104) were the least useful; anthropogenic soils were so dry as to be indistinguishable from the brown soils of the plain (Fig. 3). The most useful imagery came from Mission 1039, acquired 28 February 1967. On settlement sites, decayed mud brick architecture is strongly reflective and appears as light areas. Outside of the survey region, Mission 1039 imagery could resolve the internal structure of Nimrud's lower town, revealing wide processional ways, narrow alleys, and the variable density of intramural settlement (Ur 2013b). Although more ambiguous than at Nimrud, potential traces of internal structure are likewise visible at several large sites in the EPAS region. In addition to sites, Mission 1039 imagery records many types of off-site landscape features, including surface canals, karez shafts, and hollow ways (all discussed below). CORONA scenes were georeferenced via Google Earth-derived control points; hence their accuracy is tied directly to the accuracy of the imagery displayed in Google Earth - predominantly $2.5 \mathrm{~m}$ true-colour SPOT (Système Pour l'Observation de la Terre) satellite imagery. During the course of fieldwork, GPS-collected ground control points were used to improve the horizontal accuracy.

Other spatial data datasets included $1 \mathrm{~m}$ resolution panchromatic scenes from the OrbView-3 satellite, acquired between 2003 and 2007; $2.5 \mathrm{~m}$ resolution true colour SPOT mosaics, circa 2004 (viewable via Google Earth, as of 29 November 2012); several multispectral Landsat scenes from 2010-2011; and a 90 m digital elevation model (DEM) from the 2000 Shuttle Radar Topography Mission (SRTM). In future seasons, field survey will also be directed by site probability maps derived from classification of ASTER (Advanced Space-borne Thermal Emission and Reflection Radiometer) multispectral imagery, which has been very successful at identifying habitation sites in north-eastern Syria (Menze and Ur 2012).

Pre-fieldwork imagery analysis identified 1,200 probable archaeological sites, predominantly based on their signatures on CORONA imagery (Figure 4). It also revealed almost 7,500 karez shafts, $124 \mathrm{~km}$ of pre-modern irrigation canals, and 851 hollow way segments totaling $324 \mathrm{~km}$.

Field Mapping and Surface Collection. In this initial field season, EPAS investigated intensively two circumscribed sub-regions of the full survey area: $60 \mathrm{~km}^{2}$ around Tell Baqrta (Site 17) and $50 \mathrm{~km}^{2}$ around Qasr Shemamok (Site 2). Additionally, an area of possible surface canals was targeted for three days of opportunistic observations. For each field day, sites and features for a small portion of the survey database (generally $30-40 \mathrm{~km}^{2}$ ) were "checked out" to a GPS-enabled mobile computer (Trimble GeoXT) running ESRI ArcPad 10 mobile GIS software. Navigation was vehicular, guided by a combination of the mobile GIS data, 1:10,000 scale printed CORONA maps and Garmin GPS 60 handheld GPS receivers. Upon arrival at a potential site, one team member mapped its boundaries via GPS, subdivided it into discrete topographic collection areas, and took GPS elevations at its 

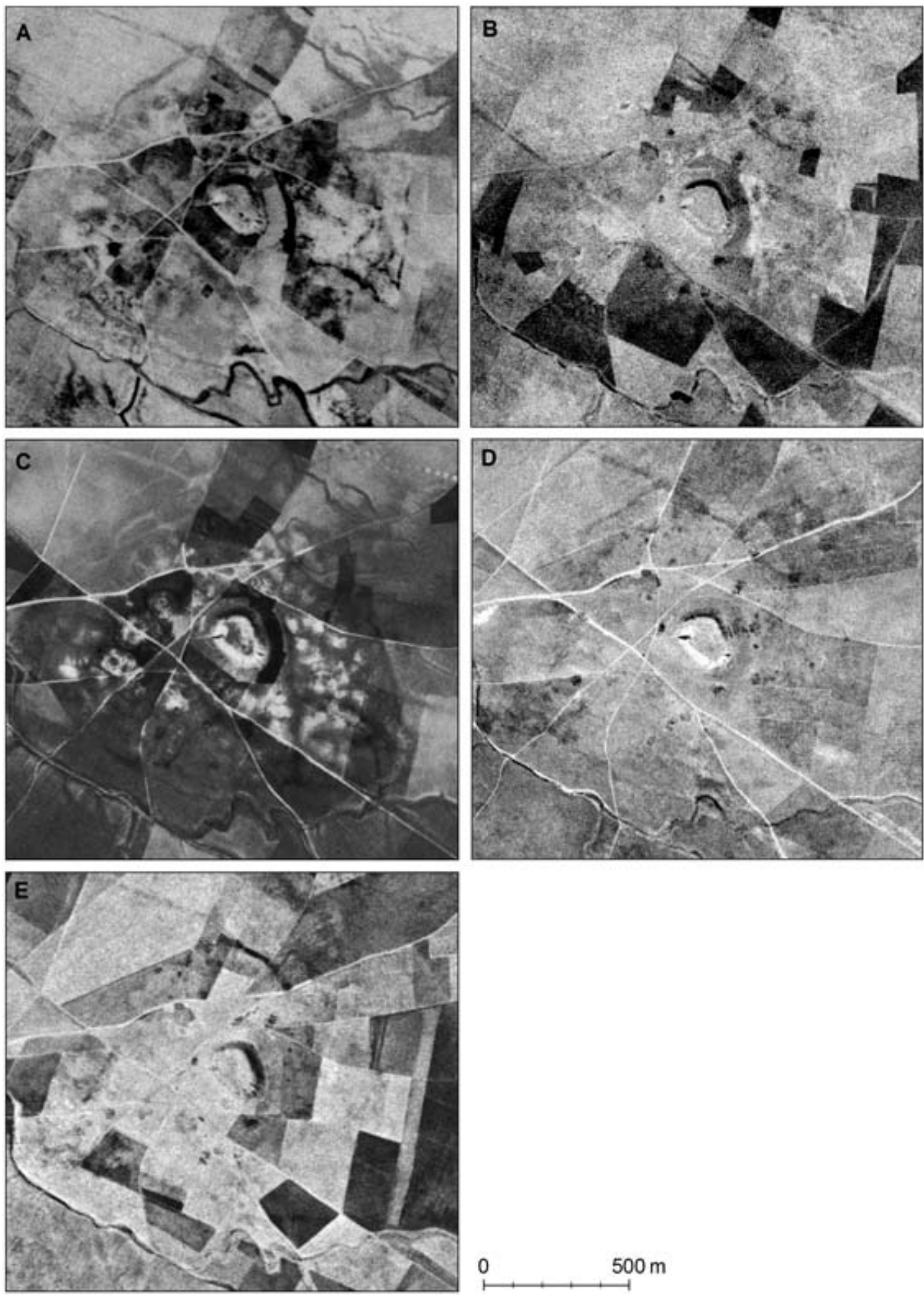

Fig. 3 Site signature on five CORONA missions at Tell Baqrta (Site 17). A. 1030-2103DA068 (16 March 1966); B. 1036-2138DA012 (18 August 1966); C. 1039-2088DA038 (28 February 1967); D. 1104-2138DF006 (16 August 1968); E. 1110-2170DA103 (3 August 1969). Note the karez in the upper right corner of $\mathrm{C}$, which is not visible in any other scene. All to the same scale. 


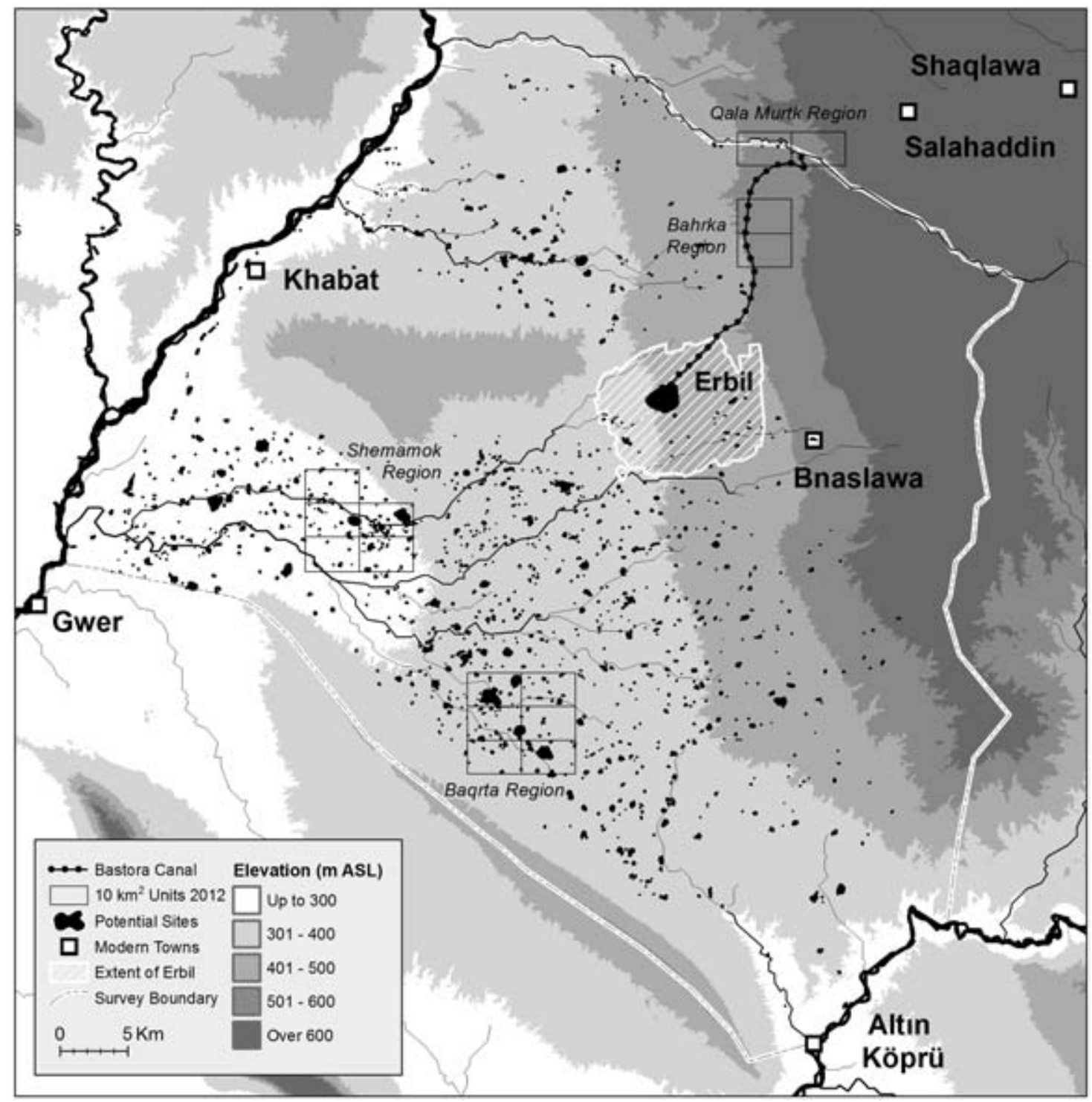

Fig. 4 Distribution of probable archaeological sites, identified from CORONA satellite imagery, including the regions surveyed in 2012.

highpoint, at the highpoints of each collection area, and at plain level on several sides. The rest of the team collected diagnostic potsherds (i.e., rims, bases, handles, and decorated body sherds) and any other significant artefacts. No attempt was made to make a complete collection, or to walk systematic transects over the sub-areas, but collectors did attempt to visit all parts of the collection area evenly.

The day's geospatial data (GPS observations of site boundaries, polygons representing site subareas, ground control points for imagery geocorrection, and various other observations made of the archaeological landscape) were downloaded from the GPS receivers. Points collected via the GeoXT could be further enhanced by "post-processing," a process by which GPS positions from a nearby reference station are used to improve the accuracy of points collected in the field. The US National Geodetic Survey manages a network of Continuously Operating Reference Stations (CORS), primarily in the US, but with six stations in Iraq. ${ }^{3}$ Each station is based atop a precisely-known point 
on the earth's surface; it takes a position from the constellation of GPS satellites at defined time intervals and then calculates the deviation from its known coordinates. The CORS within the city of Erbil takes a reading every five seconds. Its correction files can be downloaded and used to correct positions taken anywhere in the Kurdistan Region or Ninuwa Governorate. On a given day, most field positions could be corrected to $30-50 \mathrm{~cm}$ accuracy, and almost all points could be improved to less than $1 \mathrm{~m}$ positioning error on the horizontal plane. After geocorrection, field collected positions were then "checked in" to the project geodatabase.

Ceramic collections were analyzed with reference to an evolving typology of survey diagnostics. The typology is based on David Tucker's surface collection of Tell al-Hawa (Ball et al. 1989) and later expanded by Tony Wilkinson for the Iraqi North Jazira Project (Wilkinson and Tucker 1995). It was further expanded and renumbered for the surveys of Tell Brak and Hamoukar (detailed in Ur 2010b: 213-98). Counts for individual types were entered into a relational database in which periodby-period diagnostic counts could be related to their collection areas, and a ceramic surface density ratio (diagnostics per hectare) calculated. This ratio was used to determine whether some or all of a site was occupied during a given ceramic period.

\section{Preliminary results of the 2012 season}

After 18 days in the field, the EPAS site register includes ninety-three archaeological sites. Five of these sites were known previously and had been excavated: Erbil (Site 1), Qasr Shemamok (Site 2), Qalinj Agha (Site 3), Kilik Mishik (Site 4), and Tell Nader (Site 5). Of the other eighty-eight sites, roughly a dozen had been listed in the Atlas of Archaeological Sites in Iraq (Directorate General of Antiquities 1979). These ninety-three sites total 628.3 hectares of settled area, excluding Erbil itself, which could be as large as 355 hectares (based on possible city wall traces on CORONA and the assessment of Nováček 2011; see also Nováček et al. 2013, this volume).

Preliminary results suggest that the plain was urbanized from at least the late 3 rd millennium B.C. The two intensely surveyed regions both had multiple sites in excess of 45 hectares. Furthermore, there are other probable large sites, identified from CORONA but not yet confirmed on the ground, found elsewhere in the survey region. It seems certain, even at this preliminary stage of fieldwork, that the Erbil Plain is a south-eastern extension of the urbanized northern Mesopotamian plain. The initial presentation of results below will focus largely on new data for urban-scale settlements and remote sensing results; a fuller discussion of the prehistoric landscape, and patterns of urbanization and ruralization generally, will come in future reports after EPAS has examined a larger percentage of its survey region.

Early Bronze Age urbanism. Cities proliferated across the northern Mesopotamian plain in the late EBA (c. 2600-2000 B.C.), and the Erbil plain was no exception. Two large sites were identified in the survey region, one of which has unexpected characteristics compared to known sites from elsewhere in northern Mesopotamia.

Tell Baqrta (Site 17) approximates the morphology of known EBA urban sites. This important site was brought to our attention by Dr. Konstantinos Kopanias, who will direct excavations there in 2013. It consists of a high central mound four hectares in extent (Fig. 5) and an extensive lower town on all sides (see Fig. 3). The entire complex covers 80 ha. Unlike other EBA urban centres, it is not obviously walled. On most sides, its lower town appears to fade gradually into the plain, and its signature on CORONA satellite imagery shows no distinctive light line that might be interpreted as a wall.

Baqrta had a long and complex settlement history, starting at least in the early fourth millennium B.C. Settlement was limited to the central mound until the later third millennium, when the entire lower town was settled. Settlement declined sharply in the MBA but expanded again in the LBA, when it may have been as much as 20 ha. In the Neo-Assyrian period, settlement was again restricted to the high mound; at this time, the site may have been known as Baqarru. The Parthian and Sasanian periods both saw extensive but potentially low density settlement at Baqrta.

If Baqrta's entire 80 ha area was occupied in the later third millennium B.C., it joins the ranks of Hamoukar (98 ha), Leilan (90 ha), Tell Brak (70 ha) and others in the top tier of urbanized settlements (Ur 2010a:405). A site with such a complex settlement history requires a more intensive surface analysis than EPAS was able to conduct in 2012. 


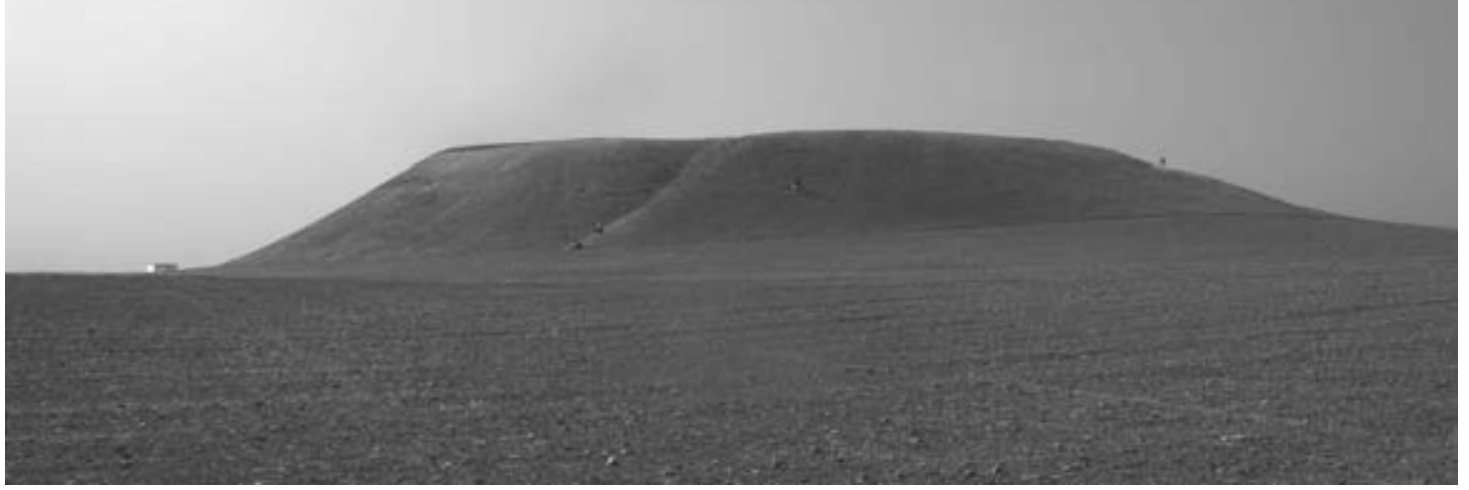

Fig. 5 The central high mound at Tell Baqrta (Site 17) from the northwest.

Baqrta appears not to have been alone in this upper tier. A second site complex, identified a kilometer east of Qasr Shemamok, comprises several spatially discrete low mounds, the highest of which stands $10 \mathrm{~m}$ over the plain (Fig. 6). These mounds were collected separately (as Sites 33, 34, $35,36,37$ and 87); it was only upon processing the collections that their contemporaneity was revealed. The centre-most mound (Site 33) has an early third millennium component; painted

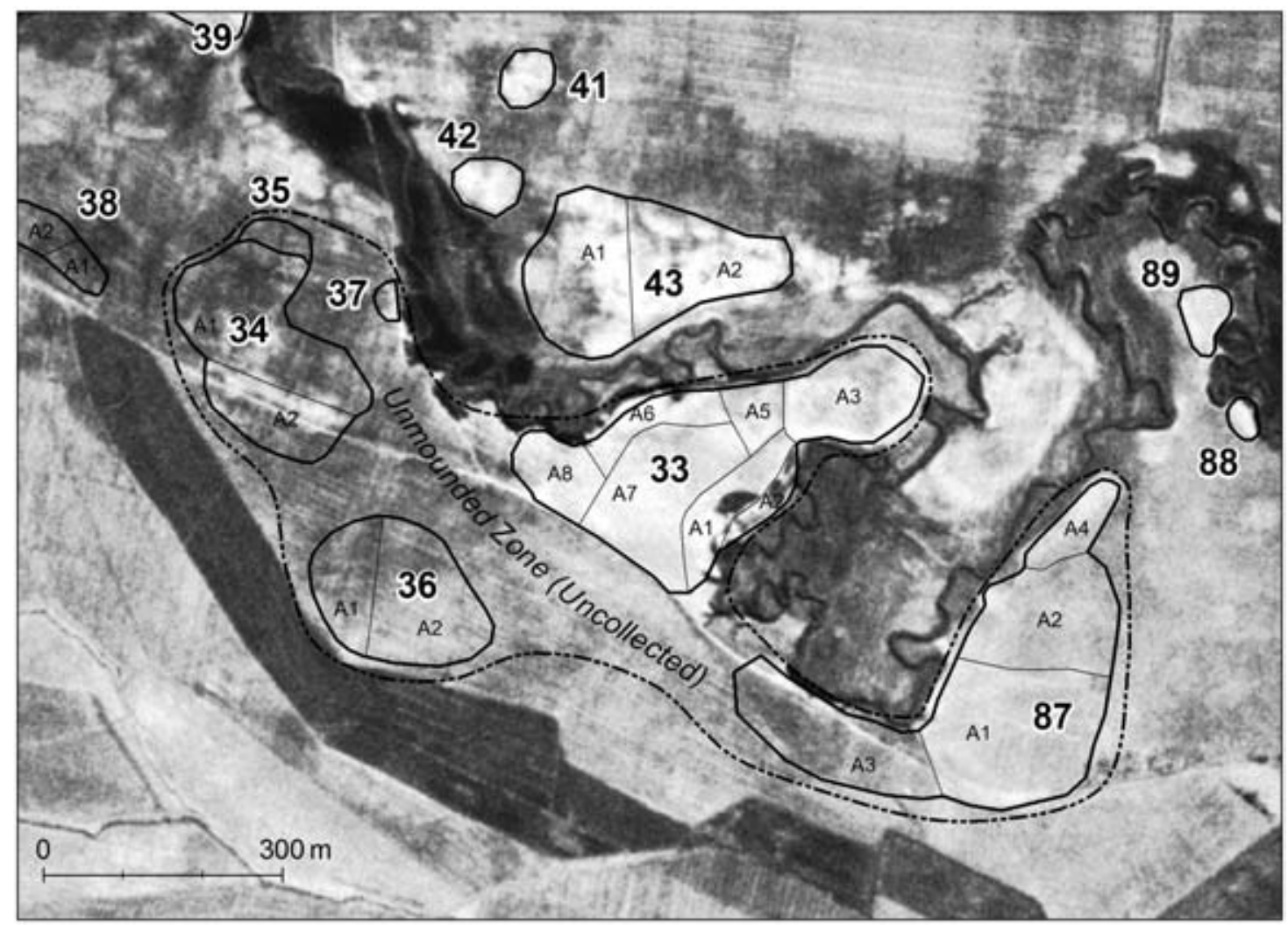

Fig. 6 Site 33 settlement complex and adjacent sites (CORONA 1039-2088DA037, 28 February 1967). Dashed line indicates the approximate extent of the Early Bronze Age complex. 
Ninevite 5 sherds are common. The outer mounds rise $1-3$ meters. All have a dense surface assemblage of later third millennium sherds, and to a lesser extent, scatters of the MBA. The mounds themselves encompass 24 ha, but the entire complex, including the space in between them, covers 55 ha. These low spaces were not investigated systematically in 2012, but will be revisited in future seasons. The Site 33 complex thus represents a substantial departure from the spatial organization of most known late third millennium urban centres in northern Mesopotamia, which tend to be uniformly settled at a high density. Its dispersed layout appears to be more reminiscent of the extensive, low density settlement form of Late Chalcolithic sites such as Khirbat al-Fakhar/Hamoukar and Tell Brak in north-eastern Syria (Al Quntar et al. 2011, Ur et al. 2007, 2011), which flourished more than a millennium earlier.

A third possible city of the EBA has only sparse support in the archaeological record at present. The citadel at Erbil has a long settlement history that includes evidence for late third millennium occupation (Nováček et al. 2008: 276; see also Nováček et al. 2013, this volume). Erbil is, however, mentioned in cuneiform texts from the final third of the third millennium onwards. The earliest references (reviewed in MacGinnis 2013) appear to be in texts from Ebla which record the issuing of silver for a messenger going to Erbil and date to the viziership of Ibbi-zikir, around 2300-2280 B.C. by the middle chronology. The next reference is in an inscription, known from an Old Babylonian copy, of the Gutian king Erridu-Pizir, who reports attacking the city along with Simurrum and Lullubum. Erridu-Pizir's reign cannot be placed definitively but is likely to date to somewhere in the time span 2200-2100 B.C. Thereafter references to Erbil become considerably more common. The city was taken by Shulgi in his forty-fifth year and by Amar-Sin in his second year, and is subsequently attested in almost 300 references in cuneiform texts up until the end of the Neo-Assyrian empire and even a few beyond that.

The MBA landscape and the kingdom of Qabrā. CORONA imagery analysis revealed a particularly large site close to the Upper Zab-Lower Zab watershed, $5.5 \mathrm{~km}$ northwest of Tell Baqrta (Fig. 7). The central part of the site appeared to consist of a small central high mound with a broad area of low anthropogenic soils covering 42 ha around it. This area in turn was surrounded by a linear but discontinuous white feature encompassing a total of $105 \mathrm{ha}$. On the basis of its CORONA signature, the site appeared to be a large walled city, corresponding to Kurd Qaburstan in the Atlas of Archaeological Sites in Iraq (Directorate General of Antiquities 1979: map 3 site 35, where it is measured at $11 \mathrm{ha}$ ).

A visit to the site (Site 31 ) confirmed the image interpretation. Its central mound rises $17 \mathrm{~m}$ above the plain at its highest; the lower town area varies between 2-4 m above the plain. Preservation of its city wall also varies, from $3 \mathrm{~m}$ at the western edge to less than a meter at the southern edge. Its settlement history began in the early third millennium on the high mound and continued, slightly increased, in the later third millennium. In the MBA it expanded off the central mound and out onto all areas of the lower town that were sampled in 2012, suggesting that its wall was constructed at this time. Settlement declined steadily from the LBA to the Sasanian period, and was increasingly restricted to the central mounded area.

Based on its size, morphology, and location, Site 31 is likely to be Qabrā, the capital of a city-state that attained prominence east of the Tigris and north of the Lower Zab in the early second millennium B.C. The name is not attested before or after the Old Babylonian period and Qabrā therefore seems to a product of the geopolitical reconfiguration that followed the fall of the Ur III empire. Little is known about Qabrā, as the great majority of references in the cuneiform documentation relate to when the city and its king Bunu-Eshtar were attacked by a coalition of Shamshi-Adad "of Ekallatum" and Dadusha of Eshnunna and to its subsequent occupation by Shamshi-Adad. The principle sources for this are the Stele of Shamshi-Adad, the Stele of Dadusha, letters and administrative documents from Mari, and letters from Shemsharra (Eidem and Læssøe 2001, Ismail and Cavigneaux 2003, Charpin 2004). Under Shamshi-Adad's administration its hinterland was settled with Turukkean deportees from Utum; it not known whether elements of the population of Qabrā were themselves deported out of the area. Shamshi-Adad's state was in any case not destined to last and at some stage his son Ishme-Dagan lost control of the area. Qabrā appears to have regained its independence under a king by the name of Ardigandi, but things did not all go well for Ardigandi 


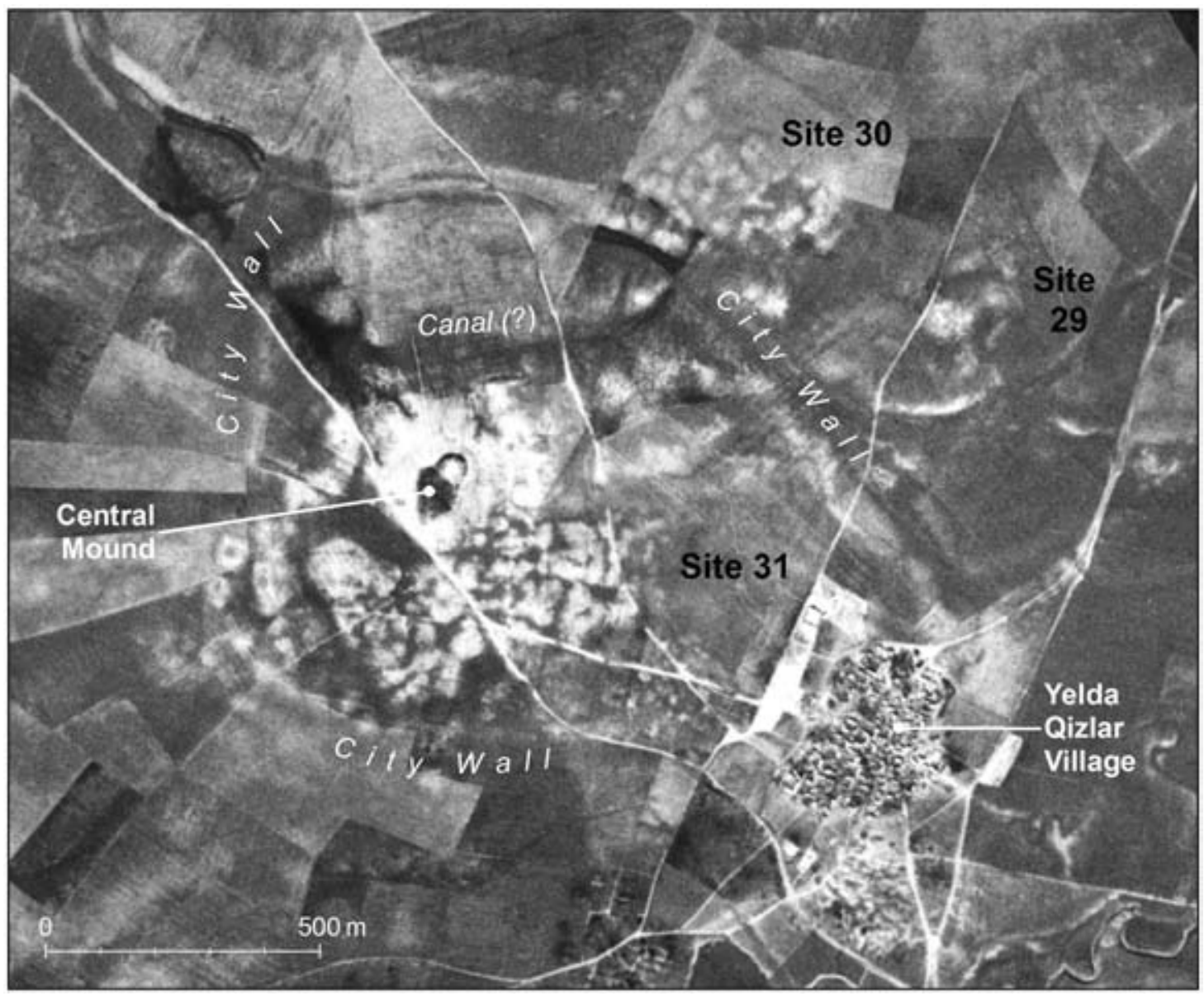

Fig. 7 The walled MBA city at Kurd Qaburstan (Site 31), possibly ancient Qabrā. CORONA 1039-2088DA038, 28 February 1967.

either; the last we hear is of his defeat and being led off into captivity at the hands of Gurgurrum, king of Kakmum.

At 105 ha, Kurd Qaburstan is comparable in size to the contemporary city at Tell Leilan (ShubatEnlil). It has other similarities to Leilan, and also to Tell al-Rimah. Its central high mound could potentially be the remains of a ziggurat (now covered by a modern cemetery). Its lower town may have been unevenly settled, and perhaps "hollow," like many other MBA administrative centres in northern Mesopotamia (Ristvet 2005: 126-28). This interpretation is drawn at present from the discontinuous nature of soil discoloration on CORONA imagery, but is not yet supported by systematic analysis of surface artifact densities. One unexpected internal feature appears to be a canal entering the lower town at the north-east, then running east-west to the north of the central mound, exiting through the city wall at its north-western corner, and then rejoining a wadi. Internal canals are a common feature of southern Mesopotamian cities at this time (Stone 2007), and certainly this region would not support such surface flow today.

Middle Assyrian urbanism at Kilizu. The largest known settlement of the Late Bronze Age in the EPAS region is Qasr Shemamok (ancient Kilizu; Site 2). The site was the administrative capital of a province of the same name (Radner 2006: 46-47). It was initially sounded by Layard and then excavated by an Italian mission (Furlani 1934, Anastasio et al. 2012). Since 2010, a French mission directed by Olivier Rouault and Maria Grazia Masetti-Rouault has investigated the site (Rouault in press, Rouault and Masetti-Rouault in press). Opportunistic observations around the site have revealed extensive surface remains of Late Bronze Age ceramics beyond its city walls, including an 


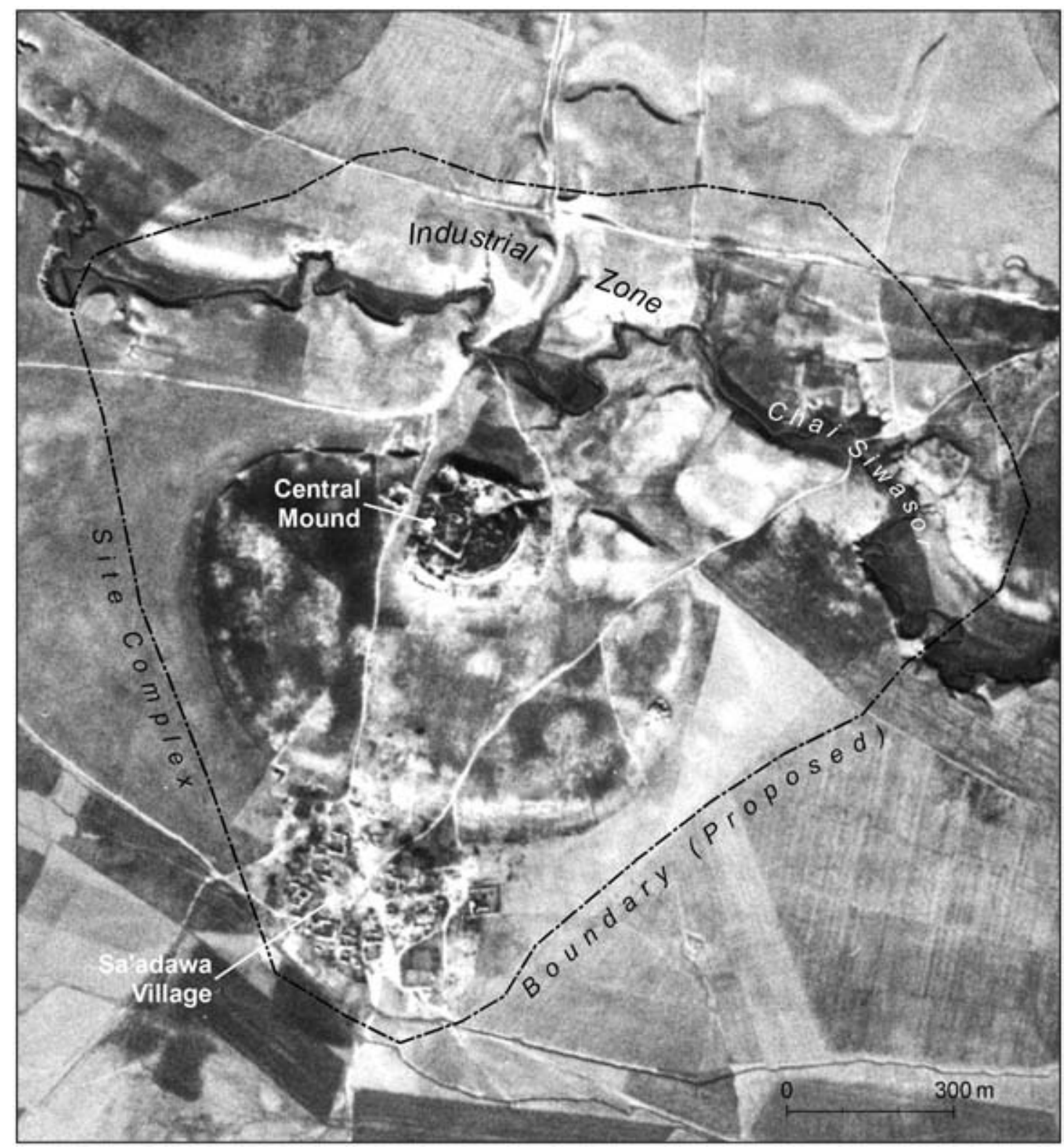

Fig. 8 The LBA/Iron Age city at Qasr Shemamok (Site 2), ancient Kilizu. CORONA 1039-2088DA037, 28 February 1967.

extensive industrial area on the opposite (north) bank of the Chai Siwasor that was probably dedicated to the firing of bricks (Fig. 8). An intensive surface collection of Qasr Shemamok and its immediate hinterland will be undertaken in the future by the French mission. On present evidence, however, it can be hypothesized that LBA settlement extended beyond the 50 ha walled city at low density, and may have included as much as 30 ha of extramural settlement on its north side. The surface evidence from Qasr Shemamok and remote sensing data for Nimrud (Ur 2013b) suggest that city walls may not be reliable indicators of the full spatial extent of Assyrian cities.

Provincial capitals in the Neo-Assyrian imperial core. Already in the later second millennium B.C, the Erbil plain was a core region of the Assyrian state, and hosted two provincial capitals at Arbail and Kilizu (Postgate 1995, Radner 2006, 2011). Despite its importance in the Neo-Assyrian empire, very little is known of the archaeology of Erbil itself, although its citadel has been subjected to a surface 
collection (Nováček et al. 2008) and salvage operations in the lower town have recovered NeoAssyrian tombs (van Ess et al. 2012). The town's extent in any given period remains difficult to ascertain, on account of the presence of the modern city of Erbil (Nováček 2011, in press). Early maps, aerial photographs, and CORONA scenes show indications of potential city walls, but these features may derive from Erbil's substantial medieval city, rather than its Assyrian one. Ancient Kilizu (Qasr Shemamok, Site 2) presents fewer problems: its city wall (50 ha) is clear both on the ground and on remote sensing datasets (see Fig. 8), and the site itself is presently being surveyed and excavated as part of a holistic approach to an early city.

For the purposes of EPAS' research objectives, the rural settlement of the plain is especially important, and the preliminary results appear to support our working model of a densely settled rural landscape. In addition to Erbil and Kilizu, EPAS recovered thirty-five other sites, only two of which exceeded five hectares in size. Most are isolated small settlements, or small-scale reoccupations of formerly large settlements. This patterning aligns well with early first millennium settlement elsewhere in the Jazira (Morandi Bonacossi 2000, Wilkinson and Barbanes 2000, Wilkinson et al. 2005), and appears to be early evidence in support of a planned and imposed agricultural colonization. Full evaluation of this model will require a larger settlement dataset and dedicated spatial analyses that are not yet possible. Additional support may come from off-site landscape features, described in the following section.

Most of these small Neo-Assyrian sites will probably remain anonymous, but it is possible to advance some thoughts on one of them. Tell Baqrta (Site 17) was at its largest in the EBA, when it may have been as big as 80 ha, but by the Neo-Assyrian period it had dwindled to a 5 ha village. While it is to be hoped that fieldwork will eventually yield cuneiform inscriptions establishing its identity in antiquity, for the moment it is interesting to note that a toponym Baqarru occurs eight times in the Neo-Assyrian corpus in texts dating from the time of Shalmaneser III to Sargon II. ${ }^{4}$ The Zamua Itinerary (Levine 1989) allows us to place Baqarru definitively in the region north of the Lower Zab. This text lists the stages on a route from Assyria to a location in the east and most likely dating to the reign of Sargon (perhaps around 710 B.C.). The remaining references make it clear that Baqarru was either a village or a small town, in a region liable to freezing in winter and subject to the normal barley tax. Tell Baqrta lies in the same region north of the Lower Zab where Baqarru is also thought to have lain. Deller's guess was that Baqarru was probably located 15-20 km northwest of Altın Köprü (1990). Tell Baqrta is almost $30 \mathrm{~km}$ from Altın Köprü, but nonetheless in the right general zone. There are other large sites in the area and other suggestions are possible. The Helsinki Atlas, for example, puts Baqarru at Tell Ya'qub, $20 \mathrm{~km}$ from Altın Köprü (Parpola and Porter 2001: 7). Nevertheless, it appears legitimate to ask whether the name Baqrta is in fact a descendant (and corruption) of Baqarru. In terms of contemporary languages, a possible etymology for baqrta might be found in Neo-Aramaic baqrata "cattle". Co-location and linguistic resonance are however not the only elements to come into play. One must also consider the archaeological evidence of the site itself. The surface remains at Tell Baqrta are consistent with a Neo-Assyrian settlement at village level.

Sasanian urbanization at Tell Khazna. Tell Khazna (Site 45) is of interest for several reasons. Its high mound has been cut by the flow of the Chai Siwasor, exposing levels of the fourth and early third millennium B.C., including abundant southern Uruk material culture. This mound is a small part of a much larger site whose sherd scatters and low mounding extends over 72 ha. The internal structure of the site is remarkably clear on CORONA imagery; especially at its northwestern end it is possible to describe streets, plazas, and probably residential blocks (Fig. 9). The high mound at the south end was fully collected, but the lower town was only sampled at large intervals. Nonetheless, it would appear to be a single-period lower town of the Sasanian era.

\footnotetext{
${ }^{4}$ A more detailed exposition of the Neo-Assyrian texts referring to Baqarru will appear in the paper by K. Kopanias, C. Beuger, J. Ur and J. MacGinnis, "The Tell Baqrta Project in the Kurdistan Region of Iraq", to be published in
}

the proceedings of the conference on the Provincial Archaeology of the Assyrian Empire held in the University of Cambridge in December 2012. 


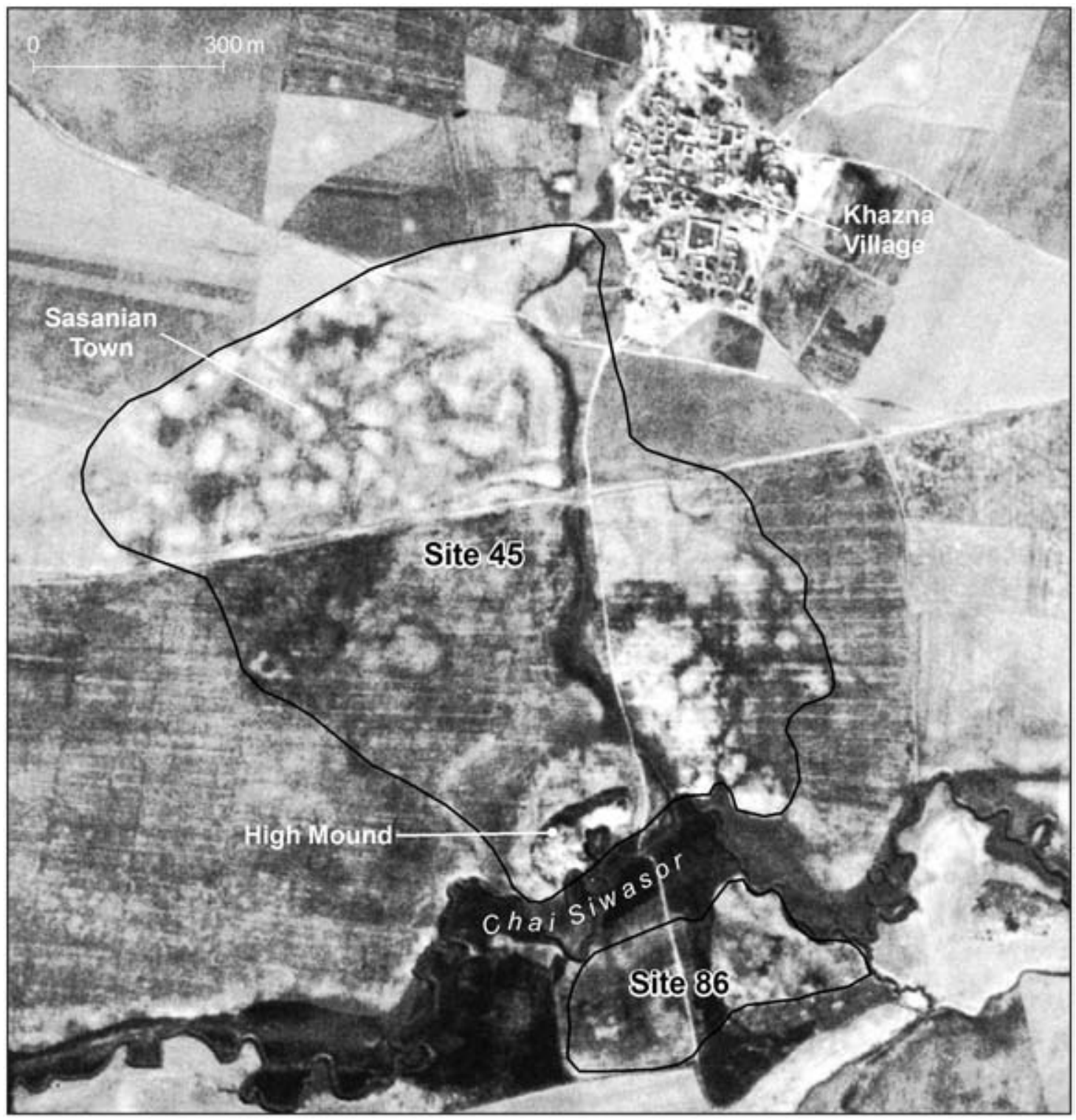

Fig. 9 The Tell Khazna (Site 45) settlement complex. CORONA 1039-2088DA037, 28 February 1967.

Medieval settlement and land use. There is substantial textual and archaeological evidence for Erbil as a large and prosperous city in the medieval period, recently reviewed by Nováček and colleagues (Nováček et al. 2013, this volume). Other large towns existed on the Erbil plain at this time. Particularly notable is Minara (Site 19), a 49 ha low mounded site with a distinctive signature on CORONA (Fig. 10). The internal structure of the settlement is revealed to be a low density agglomeration of individual structures, many of which were large courtyard-oriented compounds.

Minara is the terminus of at least a dozen karez. Several of these features emerged onto the surface at or just above the settlement, and then flowed around and possibly through it. Presumably they were used for drinking water in the settlement and for gardens and fields in the surrounding area. The seeming redundancy of the karez may be a product of the palimpsest nature of the landscape; one can imagine that under some circumstances it was easier to create a new tunnel than to restore a collapsed tunnel segment. 


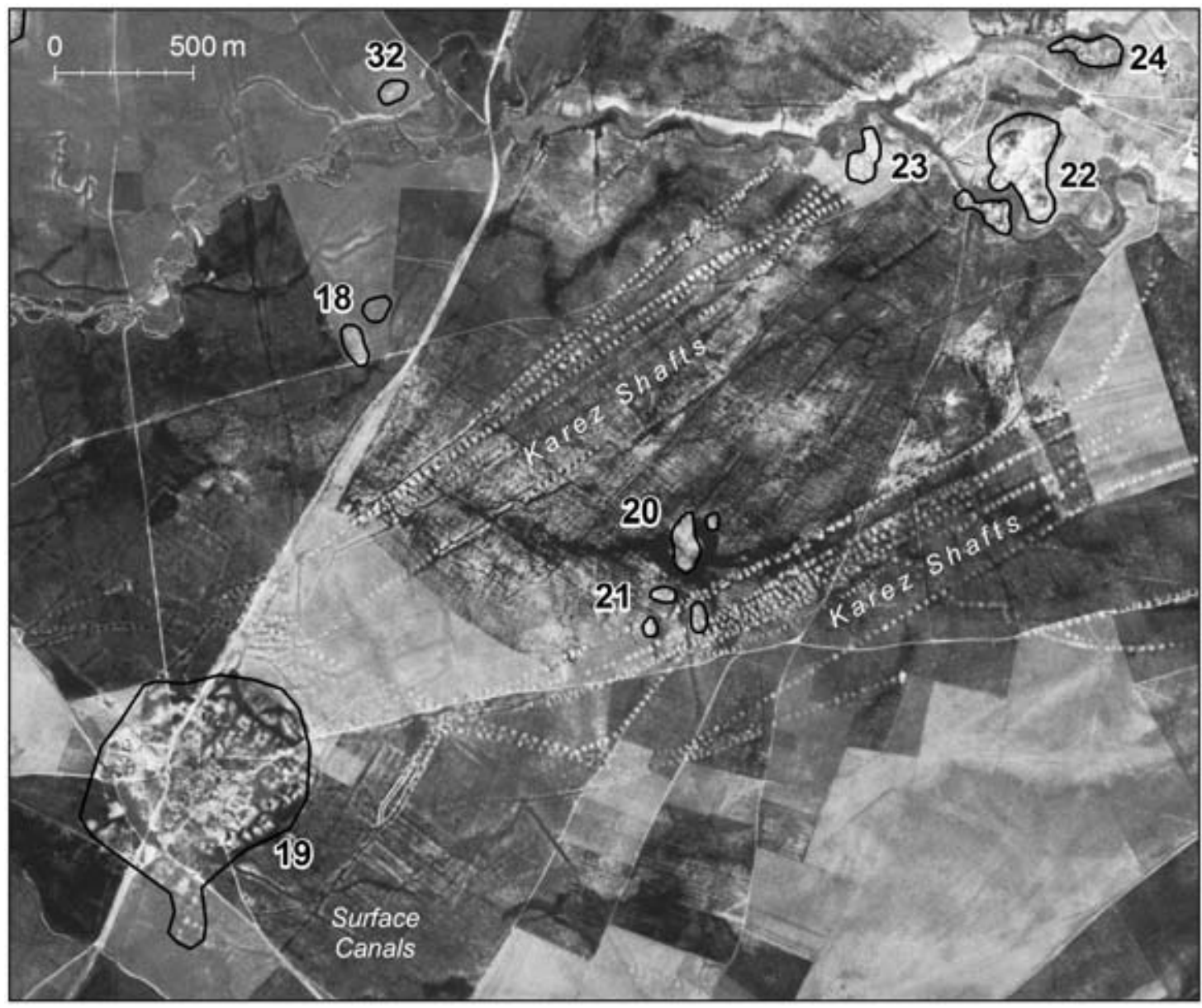

Fig. 10 Minara (Site 19), its associated karez features, and other sites in its neighborhood. CORONA 1039-2088DA038, 28 Feb 1967.

\section{The archaeological landscape of the Erbil Plain}

The plain has (until recently) preserved a spectacular array of off-site landscape features, which can be mapped extensively from CORONA satellite photographs and often also recorded on the ground. The 2012 pilot season focused on the settlement landscape; the following discussion will present initial field observations on surface irrigation and a general review of satellite-based mapping of several other kinds of features.

The only previously known ancient landscape feature in the survey region is the subterranean canal that stretched from the Chai Bastora near Qala Murtk to the environs of Erbil. The first observations were made by Fuad Safar $(1946,1947)$, who mapped and photographed the cut stone canal head, and traced a line of shafts in the direction of Erbil. He also copied the inscription, which named Sennacherib as its builder. EPAS counts among its goals the full restudy of this important feature, and dedicated three field days to the survey of its head and extent. The canal head is to be found $1.1 \mathrm{~km}$ ESE of the village of Qala Murtk (see Fig. 4), and survives largely in the same condition as at the time of Safar's visit, with one exception: local villagers say that the inscribed block was stolen in 1990 (David Michelmore, pers. comm.). The shafts of the Bastora canal proved to be elusive. Despite the known position of the canal head, unambiguous shafts or upcast rings cannot be identified in any remote sensing datasets, including the Mission 1039 (February 1967) CORONA scenes, which otherwise display abundant karez traces elsewhere in the survey region. Nor could they be located on the ground. The late-August visit coincided with very low soil moisture and no vegetation, and thus ground conditions were far from ideal. The project hopes to acquire commercial 

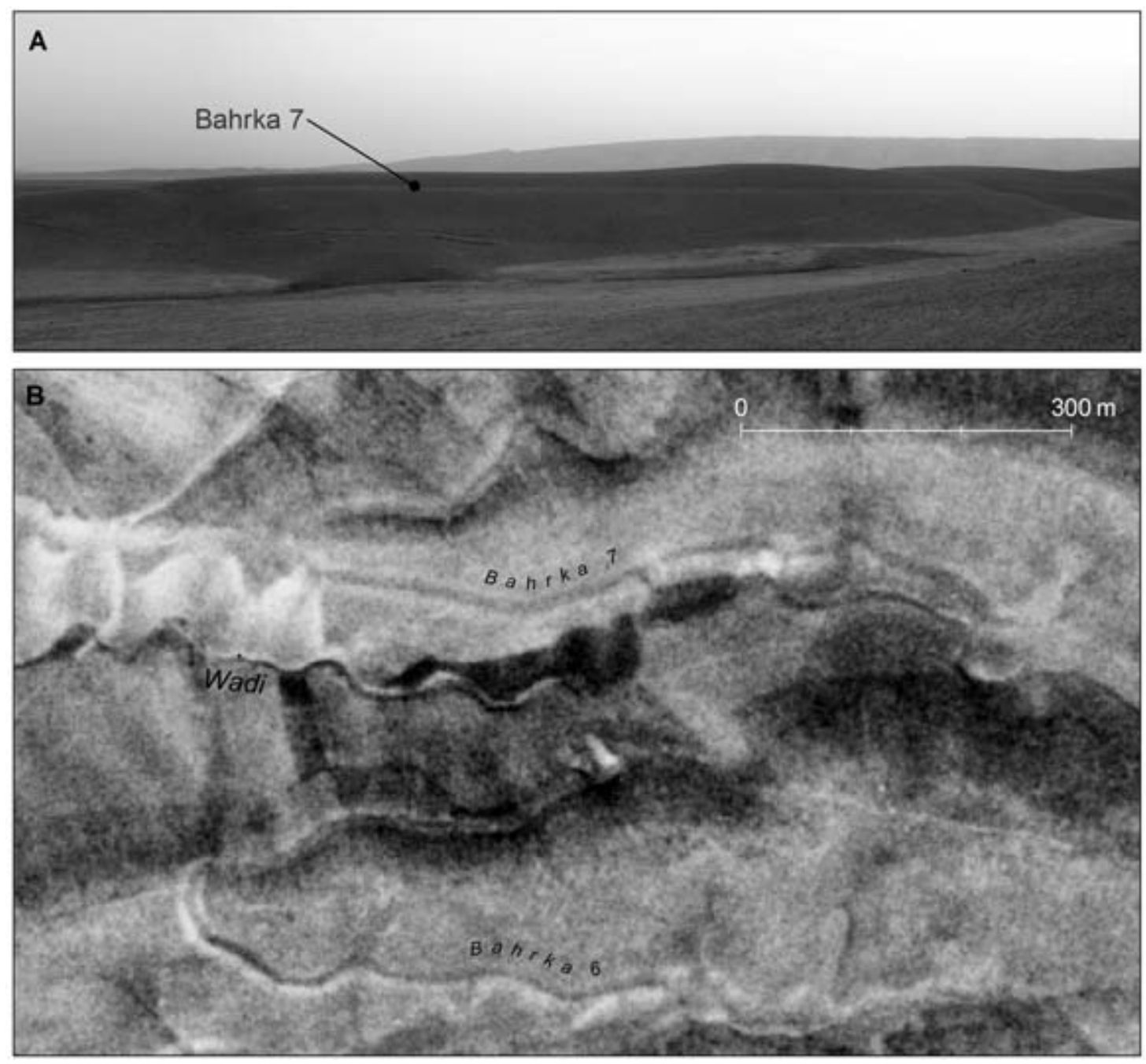

Fig. 11 A. The Bahrka 7 canal from south, taken 28 August 2012; B. The Bahrka 6 and 7 canals (CORONA 1039-2088DA036, 28 February 1967).

high resolution satellite imagery of the Bastora canal region that was acquired under better ground conditions.

Although the project failed to find the course of the Bastora canal, it did confirm on the ground a series of smaller canals. In the course of inspecting CORONA imagery for the shafts of the Bastora canal, nine linear features were seen to the east of Bahrka (named Bahrka 1 through Bahrka 9; Fig. 11). These features follow closely the contours of east-west ridges between wadis in the low hills between the Bastora canal head and Erbil. Two days of ground inspection confirmed this interpretation. The nine features' courses are all closely dictated by gravel hills into which the channels were dug. Their courses run beside the wadis, gradually gaining elevation, until they bend around to the opposite side of the ridge. By the point of this course change, they are often as much as $20 \mathrm{~m}$ above the wadi bed below. In total, EPAS could confirm $4.4 \mathrm{~km}$ of a reconstructed $9.0 \mathrm{~km}$ of excavated canals in the Bahrka region. Their widths are difficult to determine. In all cases, the canals have been infilled by erosion and are visible only as a flattened area of slightly less gravel, but they seem to be consistently about four meters wide. The canals appear to originate at the tops of the wadis, although no unambiguous diversionary features could be identified. Our cursory inspection in 2012 revealed no associated settlements, rock reliefs, nor any other relative or absolute dating evidence. 
These small features were probably used to irrigate gardens or orchards on the slopes of these gravel hills. Despite the lack of empirical support, we hypothesize a Neo-Assyrian date for these features for several reasons. The features themselves are similar in morphology and behavior to the well-known canal near the village of Faida near Dohuk, most likely to be attributed to Sennacherib (Reade 1978: 159-63, Boehmer 1997, Ur 2005: 328-30). They fall in a region of stony and unproductive soils that must have been marginal, exactly the sort of landscape that was colonized by Neo-Assyrian settlement elsewhere in the Jazira (Wilkinson and Tucker 1995: 60-62, Wilkinson et al. 2005: 37-41), and rarely in other historical periods. Finally, these canals fall along the route of the Bastora canal, as reconstructed from the sketch map of Safar (1947: map 2). It is tempting to speculate that these small canals, which today fall in a region entirely without springs, were fed by the still-unlocated subterranean channel. These speculations will of course require targeted analysis in future seasons.

The richest surface canal landscape on the plain was not visited on the ground, but could be mapped extensively via CORONA imagery. A pair of monumental canals is first visible at the far northern corner of the EPAS region, where they cut into the left bank terrace of the Upper Zab at the village of Kawr Gosk (Fig. 12). The larger of the two (Canal A) originates $1.5 \mathrm{~km}$ east of the village. It is highly linear, and can be traced almost continuously for $62 \mathrm{~km}$ along the left bank. It is remarkably consistent in width, about $55 \mathrm{~m}$ across when measured from the tops of its spoil banks (the most visible feature on CORONA imagery). It is also remarkably unresponsive to local topography, cutting through several prominences rather than bending around them. It eventually drops into the Tigris southwest of Tell Kashaf, where it had previously been identified by Altaweel (2008: 75).

The second canal (Canal B) appears to originate in Kawr Gosk village itself. This feature begins its run close to the Upper Zab terrace edge, and has been removed entirely for large parts of its course by the movements of the river. It is more variable in width, ranging from $50 \mathrm{~m}$ to $90 \mathrm{~m}$ between its spoil banks. Its course is more sinuous, and it goes around local prominences and even archaeological sites along its course. Although it originates closer to the terrace edge than Canal A, at around 24 kilometers it crosses that canal, following the natural contours of the plain away from the river and onto the alluvial plain west of Qasr Shemamok (Fig. 13). It also appears to split at this point into a more linear and deeply excavated upper channel (c. 100-120 m wide) and a more sinuous lower channel (c. $50 \mathrm{~m}$ wide). The lower canal appears to terminate in the Chai Siwasor, and the upper canal into the Chai Kurdara, and from there to flow back into the Upper Zab.

Although neither of these two monumental surface canals has been surveyed in the field, ${ }^{5}$ some hypothetical dates can be proposed, based on their morphologies, behaviors, and similarities to known canals elsewhere. In its scale and linearity, Canal A finds its best parallels in the Sasanian and Early Islamic periods, for example the Qatul al-Kisrawi and Nahrawan canals (Northedge 2005: 62-79, Adams 1965: 76-80, 2005), the massive Gorgan system (Rekavandi et al. 2007: 95-98), and the Mughan Steppe (Alizadeh and Ur 2007). Furthermore, the canal behaves with complete indifference to the Erbil plain itself; its designers' intention appears to have been to move water from the Upper Zab to the left-bank terrace of the Tigris. Hence the system is oriented to the south, perhaps toward Samarra or even the Ctesiphon-Baghdad region.

Canal B, on the other hand, finds its best parallels with the monumental canals of the NeoAssyrian empire, in particular the large canals of Ashurnasirpal's Patti-nuhšsi that brought water from the Upper Zab's right bank to the vicinity of Nimrud (Oates 1968: 45-48, Bagg 2000: 93-102, Altaweel 2008: 72-75), or Sennacherib's "Northern System", which brought water to Nineveh (Reade 1978: 157-68, Ur 2005: 325-35). Furthermore, the ultimate goal of this second canal appears to be the western extent of the Erbil plain, where over $65 \mathrm{~km}^{2}$ could have been brought under irrigation. This zone is immediately west of the provincial capital at Kilizu (Qasr Shemamok), only twenty kilometers east of Nimrud, and thirty kilometers west of Erbil. The yields of these fields could have sustained the urban populations of three of the largest cities of the imperial core. This assessment must remain speculative until the survey can identify associated settlements and obtain radiometric dates from the features themselves, planned for the 2013 field season.

\footnotetext{
${ }^{5}$ One of these features is probably the Șadr nahr Bahlūl, as it is known by local Kurdish villagers (Fiey 1965). We owe

this observation to Karel Nováček.
} 


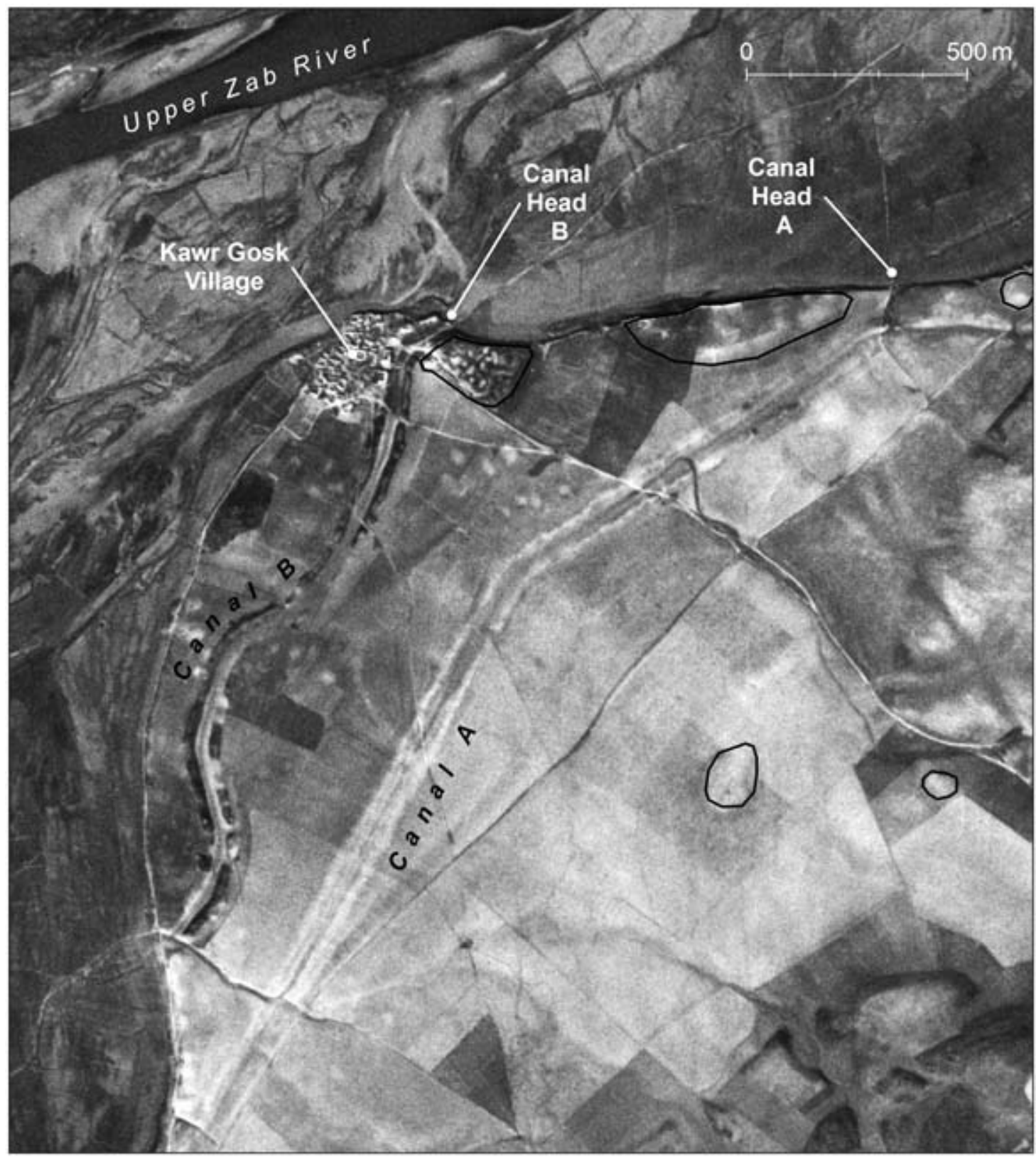

Fig. 12 Canal heads on the Upper Zab near Kawr Gosk village. CORONA 1039-2088DA036, 28 February 1967.

Another water feature found throughout the basin is the karez (Persian and Kurdish) or qanat (Arabic), a subterranean channel, excavated and maintained by means of horizontal shafts, that taps the water table and guides water to the homes and fields of villages across the plain (Goblot 1979, Beaumont 1989). Archaeological knowledge of the karez in the Erbil area is poor at present. The technology may have been introduced by the Medes or Achaemenids; the plain was irrigated by karez from the Medieval period into the twentieth century A.D., although today they are nearly extinct (Lightfoot 2009).

Karez shafts are often well preserved on CORONA photographs (Fig. 14), in one of two forms. Functioning karez had already become a rarity in the 1960s, but open shafts appear as dark spots in the centre of a circle of lighter soils. The dark spot marks the shaft itself, or a moisture-collecting 


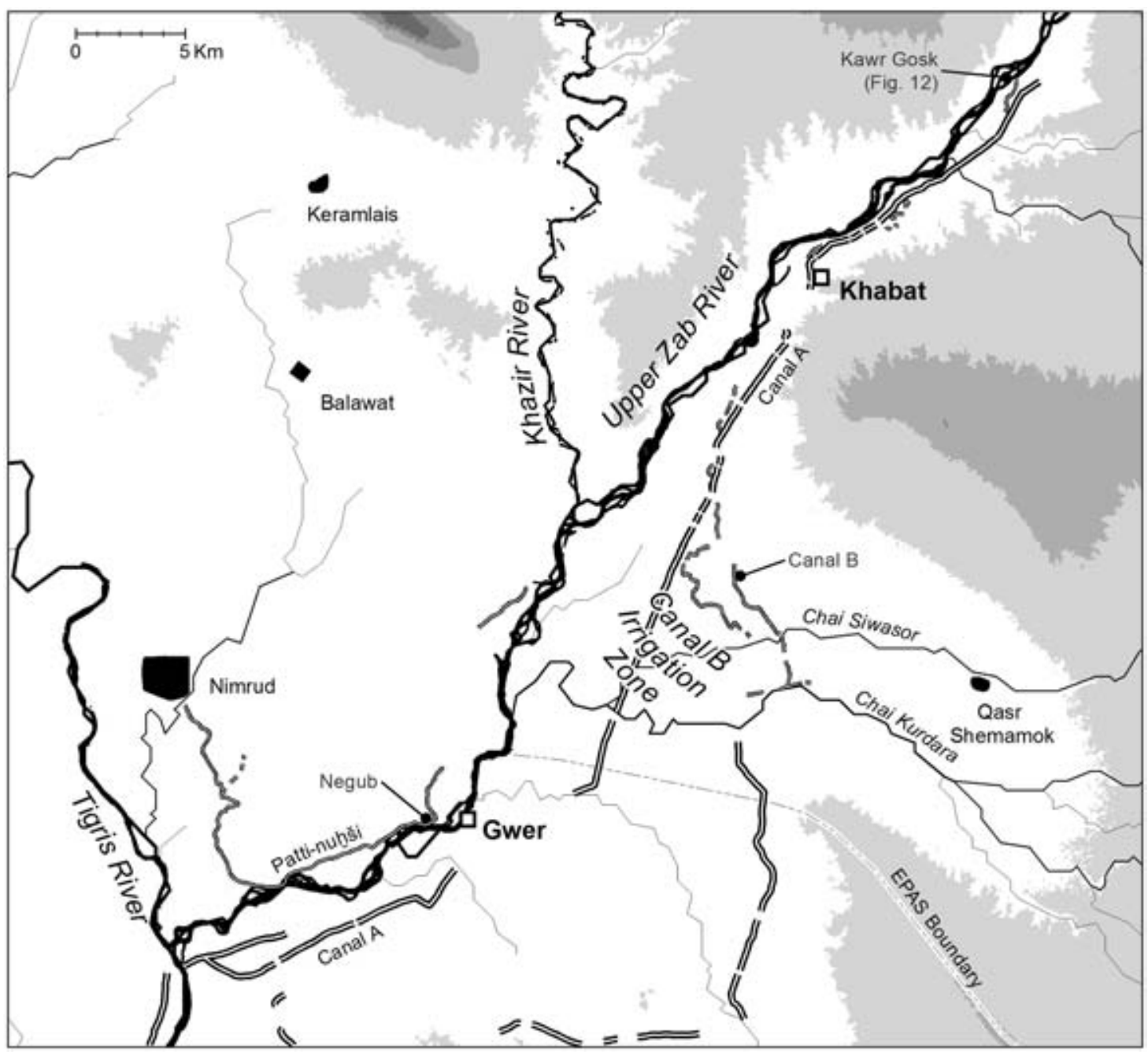

Fig. 13 Premodern canals on the Upper Zab terraces.

depression above a collapsed shaft; the light circle derives from the upcast earth from its excavation and the continuing maintenance of the subterranean channel. In the case of longer-abandoned karez, the shafts have collapsed and been plowed over, resulting in the diffusion of the upcast sediment and an appearance as a line of light spots. A non-systematic analysis of CORONA imagery of the plain has identified almost 7,500 shafts, the majority of which ran from east to west on the plain south of Erbil. Some karez can be connected to relict surface canals, but the majority of shafts were already ancient by the time the CORONA images were acquired in 1967, and their terminal surface canals had long been plowed out of existence.

Even with georeferenced CORONA and the ethnographic survey of Lightfoot (2009) as guides, it was exceedingly difficult to recognize these features on the ground. Future field seasons will aim to investigate karez remains systematically.

Two other off-site feature classes were anecdotally observed, both on the ground and via remote sensing. Hollow ways are a class of broad and shallow linear features found throughout the Near East but especially in the Jazira of Syria and northern Iraq (Wilkinson 1993, Ur 2003, 2010b: 12646). On the Erbil plain, hollow ways are abundantly visible in February 1967 CORONA satellite photographs, with a particular concentration between Erbil and Altın Köprü. Other concentrations occur northwest of Erbil, and on the northern and southern fringes of the alluvial plain between Erbil and the Upper Zab. In total, 851 features totaling 323.6 kilometers have been identified. These 

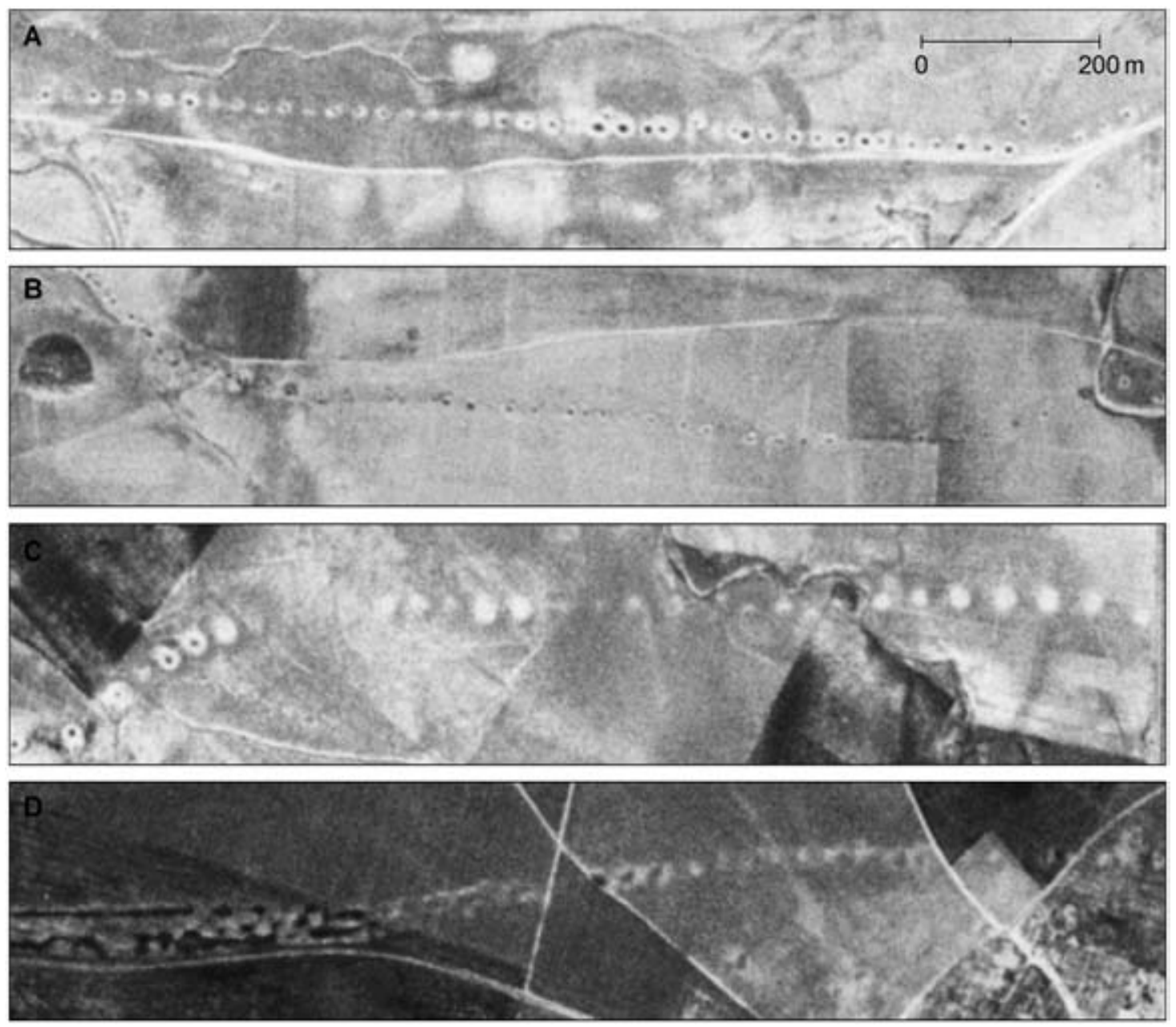

Fig. 14 Karez signatures on CORONA imagery. A. Gichka karez near Qushtepe Gawra village (dried 1970; Lightfoot 2009 Appendix A no. 58); B. Ababakir karez near Jazhnikan village (dried 1993; Lightfoot 2009 Appendix A no. 38); C. Long-abandoned karez near Qushtepe; D. Long-abandoned karez NW of Site 27 (Surezha), with associated surface canals. All images to the same scale (CORONA 1039-2088D, 28 February 1967).

zones of abundant hollow ways have two common characteristics. They appear to have hosted dense sedentary occupation, based on interpretation of CORONA imagery, and they are outside of the main regions of canal and karez irrigation. For example, to the south of Erbil, hollow ways are common in the region where karez waters are flowing in subterranean channels, but their frequency drops dramatically in the part of the plain where these channels emerge onto the surface. It appears, therefore, that taphonomic factors, mostly the destructive power of irrigation, have produced the irregular spatial distribution of hollow ways visible on CORONA satellite photographs. Taphonomic factors are also probably responsible for the relatively low density of hollow ways on the Erbil plain. The $0.10 \mathrm{~km}$ of hollow ways per $1000 \mathrm{~km}^{2}$ on the Erbil plain is less than a quarter of the density of features on Upper Khabur basin of Syria, where they occur at a density of $0.43 \mathrm{~km} / 1000 \mathrm{~km}^{2}$ (based on Ur 2010b: maps 2-3).

Across northern Mesopotamia, the terrain between sites is covered with a scatter of artifacts, mostly potsherds, of continuous distribution but variable density. These scatters have been studied systematically around Tell al-Hawa, Hamoukar, and Tell Brak (Wilkinson and Tucker 1995: 19-23, Ur 2010b: 65-76, Ur et al. 2011: 10-12). They are best interpreted as the result of manuring, the deliberate application of settlement-derived debris onto fields in order to raise crop yields (Wilkinson 


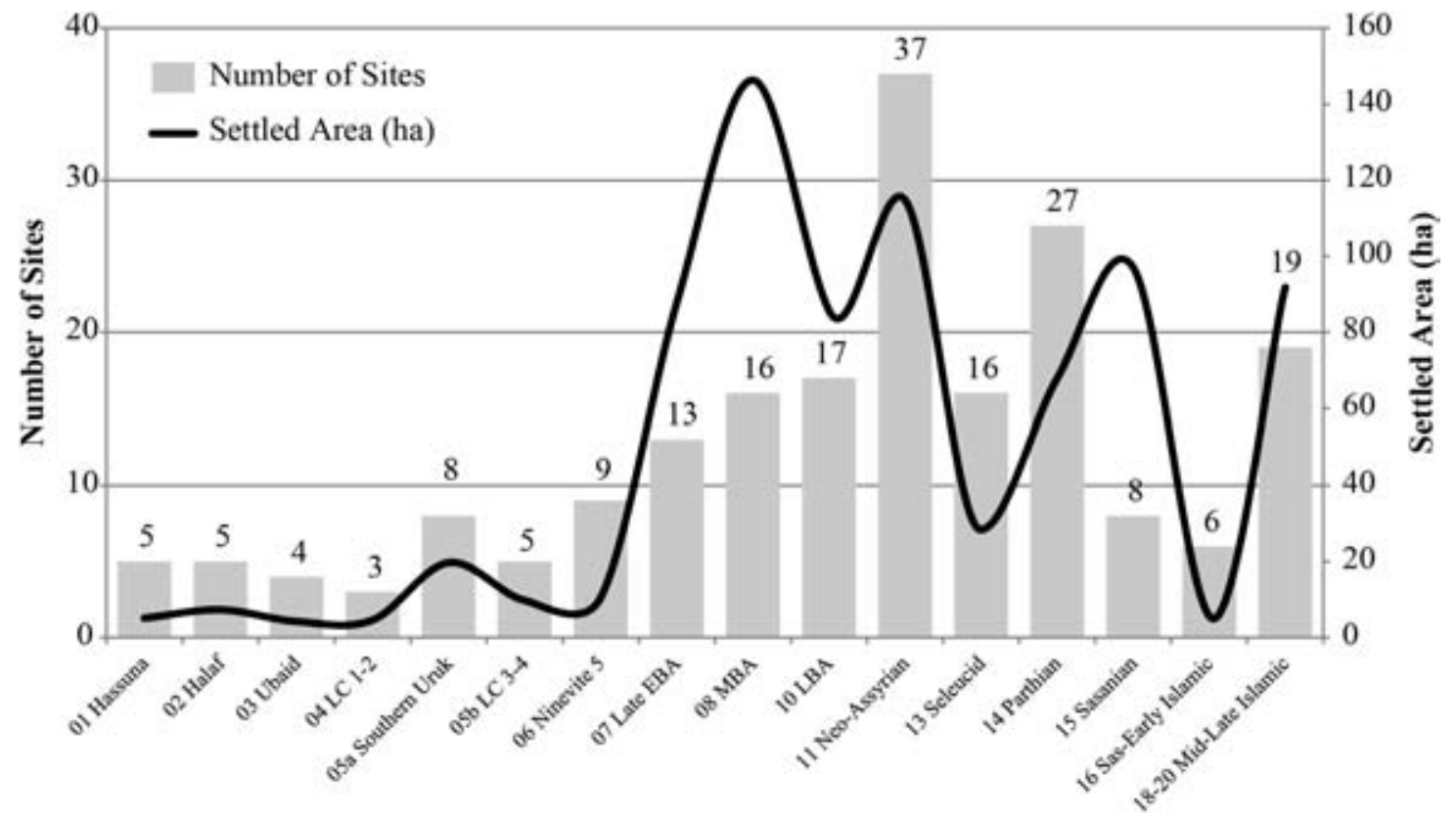

Fig. 15 Preliminary histogram of settlements recovered in the 2012 EPAS field season. Gray bars are numbers of sites, read against the left vertical axis; black line is the total settled hectares (in ha, not including Erbil), read against the right vertical axis.

2003: 117-19). Systematic observations have not yet been made, but casual observations made while walking between sites in the 2012 season suggest that farmers on the Erbil plain also employed this method. Densities appear to be especially high in the region of Tell Baqrta, which was largely outside of the zones of canal and karez irrigation. Tell Baqrta attained its greatest extent in the later third millennium B.C., the time for which field scatters are most dense elsewhere in northern Mesopotamia. Future EPAS seasons will have a dedicated field scatter collection component.

\section{Discussion}

The results of the initial season of survey are suggestive of trends in settlement and land use, but are insufficiently extensive to allow for any confidently-reconstructed historical narrative. Nonetheless, some initial observations on long-term trajectories can be made (Fig. 15), with the caveat that they are based on the Tell Baqrta and Qasr Shemamok regions, a small and possibly non-representative subset of the entire plain.

Prehistoric settlement consisted of small and infrequent villages. Site numbers began to rise only at the end of the fourth millennium B.C. Throughout the Bronze Age, settlement density varied slightly between 0.12 and 0.15 sites per square kilometer. Total settled area (and by extension, population) grew dramatically, however. Under the influences of Tell Baqrta (Site 17) in the EBA, Kurd Qaburstan (Site 31) in the MBA, and Qasr Shemamok (Site 2) in the LBA, Bronze Age average site size grew within the sampled areas of the plain. These urbanized settlement patterns match the results of intensive surveys in nearby parts of the Jazira (e.g., Wilkinson and Tucker 1995: fig. 50, Ur 2010b: fig. 6.33).

The Iron Age/Neo-Assyrian period saw a $118 \%$ rise in the number of sites, from seventeen in the LBA to thirty-seven in the early first millennium BC. The settled area curve in the settlement histogram (Fig. 15) also has a peak in the Neo-Assyrian period. Although it is accurate to describe this settlement pattern as urbanized (and indeed, the settled area calculation does not include Erbil itself), this urban system is inordinately primate; almost half of the settled area is represented by Qasr Shemamok (50 ha within the city walls). If Qasr Shemamok is disregarded, the remaining thirty-five sites account for only $64.3 \mathrm{ha}$, an average of only 1.8 ha per site. In other words, the rural landscape beyond Erbil and Kilizu appears to be composed of uniformly small villages or farmsteads. 
This pattern matches some of the expectations of an agricultural landscape deliberately colonized by deportee communities, and it mirrors analyses for elsewhere in the Jazira and western Syria (Wilkinson et al. 2004: table 14.2, Wilkinson et al. 2005: fig. 9).

These initial results also provide an opportunity to evaluate the EPAS remote sensing-based site identification methodology. In 2012, the team visited 112 CORONA-identified probable sites; 79 were confirmed (71\%) and $33(29 \%)$ proved to be "false positives," places with a site-like appearance on CORONA imagery but without other site characteristics on the ground (i.e., unmounded and without site-level surface artifact density). This rate should improve in future seasons as the team improves its imagery interpretation skills.

CORONA analysis found most but not all archaeological sites. Of the eighty-eight previously unsurveyed sites documented by EPAS in 2012, 16\% were only recognized at the time of field visit. The CORONA site identification method did, however, find most of the total area. Ninety-six percent of confirmed settled area had been identified on CORONA. In other words, the fieldidentified sites were uniformly small, on average only 1.76 ha. Thus the CORONA-based methodology is very successful for all but the tail end of the settlement system, where it could be failing to identify as many as one out of every five sites.

Such small sites are especially important for the evaluation of the hypothesis of a planned Neo-Assyrian settlement landscape. EPAS intends to elevate its recovery rate for these tail-end sites by employing a semi-automated method of classifying multi-spectral ASTER satellite imagery and digital elevation models that has been employed with great success in adjacent areas of north-eastern Syria (Menze et al. 2006, Menze and Ur 2012). With its $15 \mathrm{~m}$ pixel resolution, a one-hectare settlement would occupy over 40 pixels in an ASTER image, and indeed the method proved effective in identifying such small sites in the Hamoukar and Beydar survey areas. The Erbil plain is characterized by similar alluvial soils and semi-arid climate, and it is anticipated that this classifier method will be equally successful when ground-tested in the 2013 field season.

A final general observation can be made about the Erbil plain in relation to other surveyed landscapes in Mesopotamia. Apart from the anecdotal data provided by the few previous excavations, and the information from the Atlas of the Archaeological Sites in Iraq, the Erbil plain (and indeed, the Kurdistan Region generally) was mostly unknown before the 2012 EPAS field season. It has already proven, however, to be one of the most densely settled archaeological landscapes in greater Mesopotamia (Fig. 16). The classic surveys of southern Iraq generally recovered $0.1 \mathrm{sites} / \mathrm{km}^{2}$. More recent intensive surveys in northern Mesopotamia recovered sites at a rate between 0.4 and 0.5 sites/ $\mathrm{km}^{2}$. ASTER-based virtual survey of north-eastern Syria produced a similar rate if one only considers mounded sites, but exceeds 0.6 sites $/ \mathrm{km}^{2}$ for all sites (including flat sites, which are more likely to be false positives). The surveyed $110 \mathrm{~km}^{2}$ of the EPAS region has a confirmed density of 0.77 sites $/ \mathrm{km}^{2}$. This ratio does not include ninety-two potential sites within the Baqrta and Shemamok areas that have not yet been visited. The assessment of CORONA-based site identification above would suggest that $71 \%$ of these sites would be confirmed, which would result in a settlement density of $1.37 \mathrm{sites} / \mathrm{km}^{2}$. At the scale of the entire EPAS region $\left(3,200 \mathrm{~km}^{2}\right)$, CORONA analysis has identified 1,200 probable sites for a density of 0.38 sites $/ \mathrm{km}^{2}$. This rate, which includes agriculturally marginal areas like the Demir Dagh ridge and the hills west of Erbil, is more in line with the recovery rates of recent northern Mesopotamian surveys.

It is necessary to consider several caveats in interpreting this comparative data, however. The site densities of the southern Mesopotamian surveys of Adams and colleagues are low for methodological and taphonomic reasons. They did not have access to GPS or GIS technologies, satellite imagery, or even decent maps. Furthermore, the southern plains have been subjected to a range of transformative processes, the most significant of which is an aggradation of silts that have buried many archaeological sites meters beneath modern plain level (Wilkinson 2003: 80-82). The recent surveys in northern Mesopotamia all treat much smaller survey universes, which allow them to be far more intensive, with a correspondingly higher recovery rate. The high density recognized on the Erbil plain is certainly related to new methodological innovations in GIS and the easy availability of remote sensing tools (especially CORONA imagery), neither of which were available to surveyors prior to the late 1990s. It seems equally certain, however, that the major contributing factor is simply 


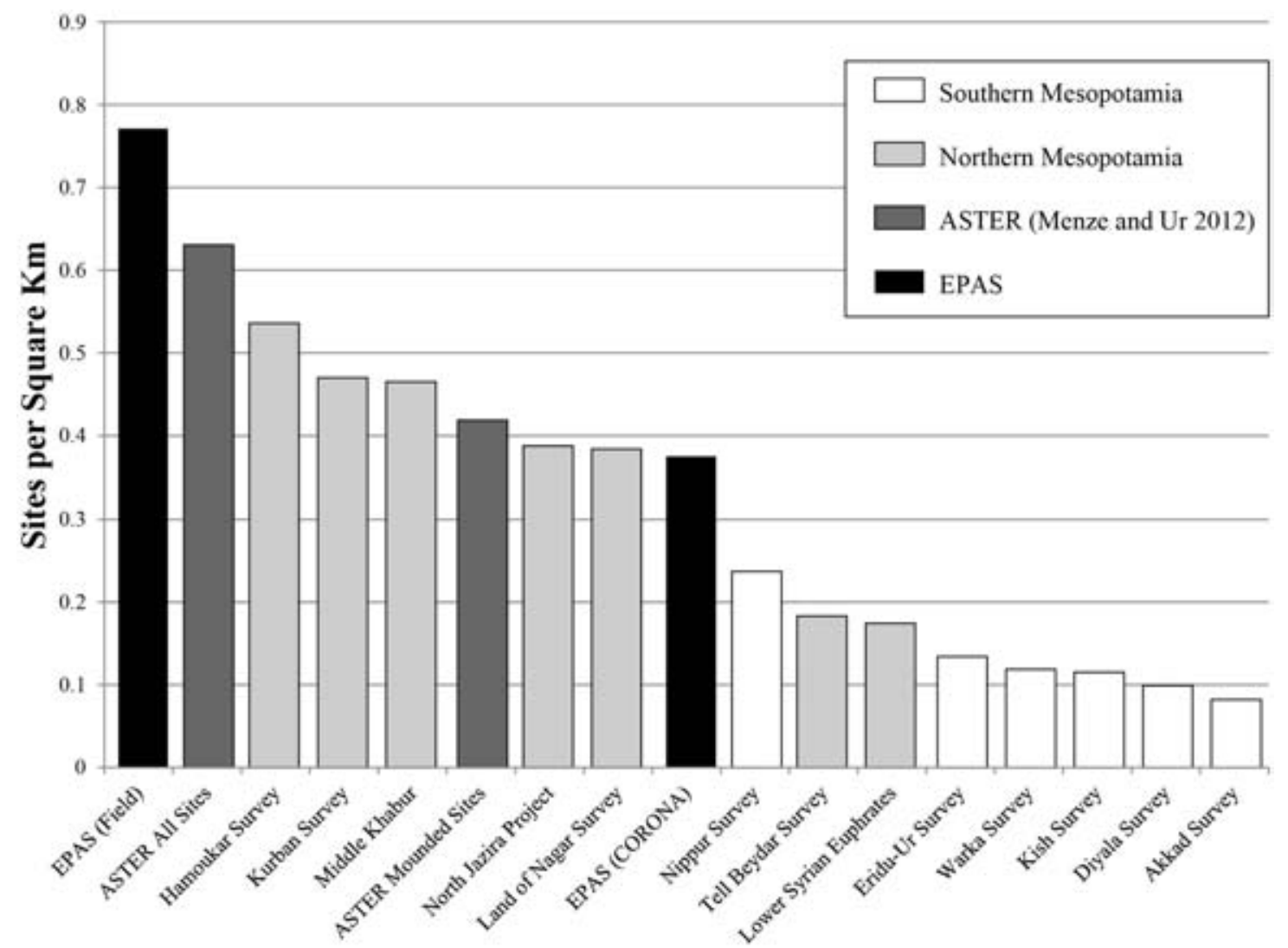

Fig. 16 Comparative site densities/recovery rates for Mesopotamian surveys (based on Adams 1965, 1981, Adams and Nissen 1972, Gibson 1972, Wright 1981, Geyer and Monchambert 2003, Monchambert 1984, Wilkinson 1990, Eidem and Warburton 1996, Ur 2010b, Menze and Ur 2012, Wilkinson and Tucker 1995).

the rich history of settlement on the Erbil Plain - a feature all the more striking because of the former disregard of the region by archaeological research.

\section{Conclusions and future prospects}

In its pilot season, the Erbil Plain Archaeological Survey has revealed a new zone of early urbanism and social complexity on the eastern edge of the Fertile Crescent. This situation is entirely unsurprising, given the known trajectories of settlement in adjacent regions of similar environments. It does, however, demonstrate how the vagaries of archaeological exploration and modern politics can conspire to keep us in the dark about entire regions of major archaeological significance. New landscape research in Suleimaniya (Mühl 2010, Altaweel et al. 2012) and Dohuk (Daniele Morandi Bonacossi, pers. comm.) will reinforce this impression. One can only imagine what we will learn about landscapes on the Sinjar and Kirkuk plains, once intensive, remote-sensing driven field research can be undertaken in the future.

Upcoming EPAS seasons will focus on Holocene settlement landscapes, with particular attention to the first millennium B.C. The project will expand the regions of intensive full-coverage settlement survey to include the greater hinterlands of Qasr Shemamok, Tell Baqrta, and Kurd Qaburstan, and to investigate the terraces of the Upper and Lower Zab rivers. Future settlement survey will be guided by ASTER-based remote sensing using the 2012 results as input into the classifier. Much of the off-site landscape remains known only from CORONA analysis; future seasons will target canal, karez, and hollow way features and their associated settlement landscapes. 


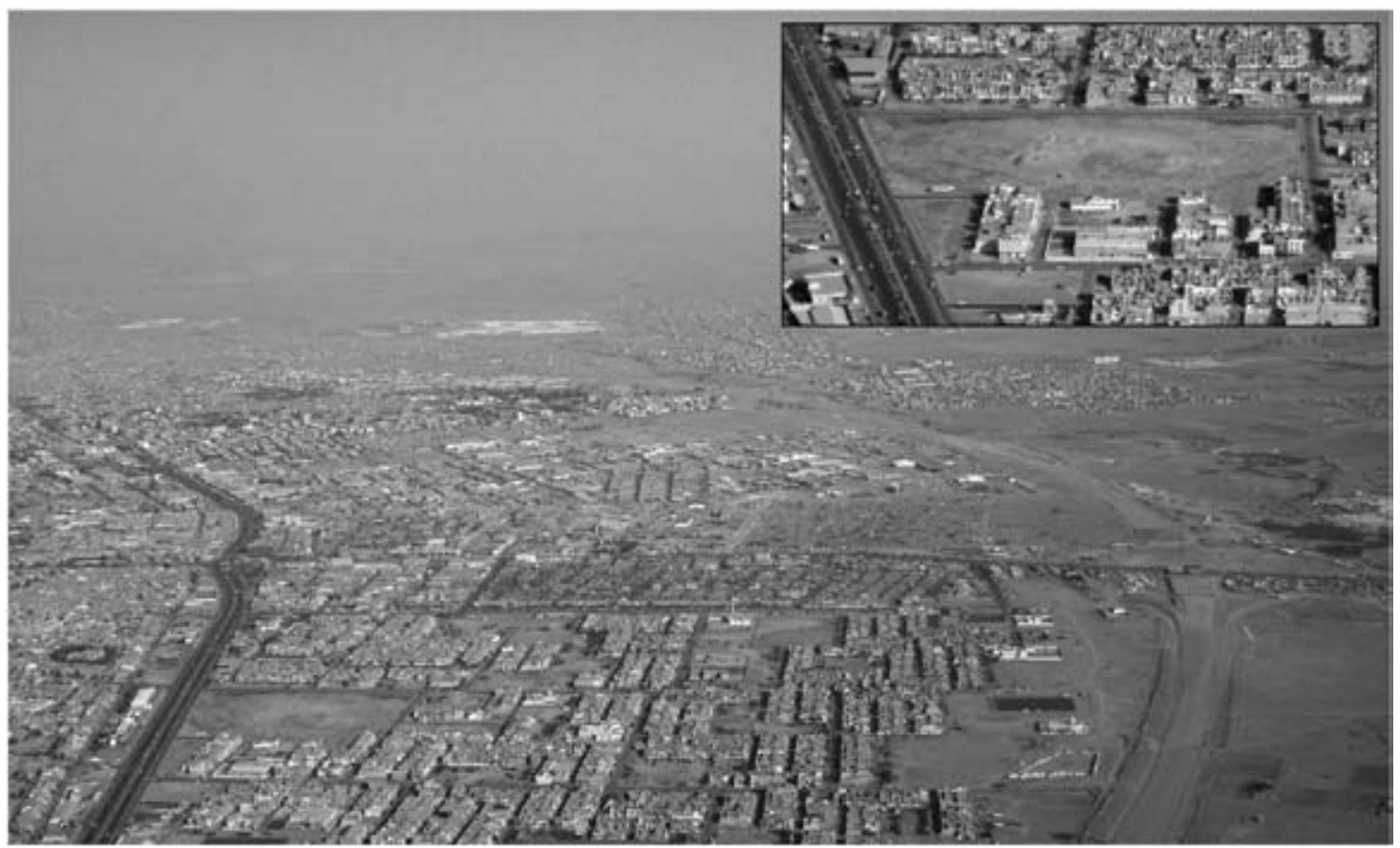

Fig. 17 Urban sprawl in south Erbil (7 September 2012). The new 120-m ring road is under construction at right. At lower left, the site of Kilik Mishik (Site 4) now survives as an island in the midst of the city. Inset: detail of Kilik Mishik.

Based on our observations in 2012, this work has a new sense of urgency. The Kurdistan Region generally, and the Erbil region specifically, is in the early stages of economic boom, after decades of under-development. The expansion of towns and new development projects are taking a serious toll on the cultural landscape, which appears to have escaped the effects of such development until only recently. Nowhere is this situation more serious than along the expanding fringes of the city of Erbil (Fig. 17). In the 1940s, the city covered approximately half a square kilometer. By August 1968, the city's ring road encompassed $7.6 \mathrm{~km}^{2}$, with an additional $3.5 \mathrm{~km}^{2}$ beyond it. By March 2000, the city encompassed $44.2 \mathrm{~km}^{2}$, growing to an estimated $137 \mathrm{~km}^{2}$ by September 2011, as new outer neighborhoods have appeared to accommodate returnees from Europe and internally displaced persons from elsewhere in Iraq. As development gains momentum, more sites and landscape features are disappearing beneath the city. In future seasons, EPAS intends to target the most threatened areas of urban expansion for salvage survey.

\section{Bibliography}

Adams, Robert McCormick. 1965. Land Behind Baghdad. Chicago: University of Chicago Press.

-. 1981. Heartland of Cities. Chicago: University of Chicago Press.

-. 2005. "Intensified Large-Scale Irrigation as an Aspect of Imperial Policy: Strategies of Statecraft on the Late Sasanian Mesopotamian Plain," in Agricultural Strategies. Edited by Joyce Marcus and Charles Stanish, pp. 17-37. Los Angeles: Cotsen Institute of Archaeology.

Adams, Robert McCormick, and Hans J. Nissen. 1972. The Uruk Countryside. Chicago and London: University of Chicago Press.

Al Quntar, Salam, Lamya Khalidi, and Jason A. Ur. 2011. Proto-Urbanism in the late 5th Millennium BC: Survey and Excavations at Khirbat al-Fakhar/Hamoukar, Northeast Syria. Paléorient 37:151-75.

Alcock, Susan E. 1994. "Breaking Up the Hellenistic World: Survey and Society," in Classical Greece: Ancient Histories and Modern Archaeologies. Edited by Ian Morris, pp. 171-90. Cambridge: Cambridge University Press.

Alizadeh, Karim, and Jason A. Ur. 2007. Formation and Destruction of Pastoral and Irrigation Landscapes on the Mughan Steppe, North-Western Iran. Antiquity 81:148-60.

Altaweel, Mark. 2003. The Roads of Ashur and Nineveh. Akkadica 124:221-28. 
-. 2005. The Use of ASTER Satellite Imagery in Archaeological Contexts. Archaeological Prospection 12:151-66.

- 2008. The Imperial Landscape of Ashur: Settlement and Land Use in the Assyrian Heartland. Heidelberger Studien zum Alten Orient 11. Heidelberg: Heidelberger Orientverlag.

Altaweel, Mark, Anke Marsh, Simone Mühl, Olivier Nieuwenhuyse, Karen Radner, Kamal Rasheed, and Saber Ahmad Saber. 2012. New Investigations in the Environment, History, and Archaeology of the Iraqi Hilly Flanks: Shahrizor Survey Project 2009-2011. Iraq 74:1-35.

Anastasio, Stefano, Giovanni Conti, and Laura Ulivieri. 2012. La collezione orientale del Museo Archeologico Nazionale di Firenze Volume I. I materiali di Qasr Shamamuk. Rome: Aracne.

Bachmann, W. 1927. Felsreliefs in Assyrien: Bawian, Maltai und Gundük. 52. wissenschaftliche Veröffentlichung der Deutschen Orient-Gesellschaft. Leipzig: J.C. Hinrichs'sche Buchhandlung.

Bagg, Ariel M. 2000. Assyrische Wasserbauten: Landwirtschaftliche Wasserbauten im Kernland Assyriens zwischen der 2. Hälfte des 2. und der 1. Hälfte des 1. Jahrtausends v. Chr. Baghdader Forschungen Band 24. Mainz am Rhein: Philipp von Zabern.

Ball, W., D. Tucker, and T.J. Wilkinson. 1989. The Tell al-Hawa Project: Archaeological Investigations in the North Jazira. Iraq 51:1-66.

Beaumont, Peter. 1989. "The Qanat: A Means of Water Provision from Ground Sources," in Qanat, Kariz and Khattara: Traditional Water Systems in the Middle East and North Africa. Edited by Peter Beaumont, Michael E. Bonine, and Keith McLachlan, pp. 13-31. London: Middle East Centre, School of Oriental \& African Studies.

Boehmer, Rainer Michael. 1997. Bemerkung bzw. Ergängungen zu Gerwan, Khinis und Faidhi. Baghdader Mitteilungen 28:245-49.

Buringh, P. 1960. Soils and Soil Conditions in Iraq. Baghdad: Republic of Iraq Ministry of Agriculture.

Challis, Keith. 2007. Archaeology's Cold War Windfall: The CORONA Programme and Lost Landscapes of the Near East. Journal of the British Interplanetary Society 60:21-27.

Charpin, Dominique. 2004. Données nouvelles sur la régoin du Petit Zab au XVIIIe siècle av. J.C. Revue d'assyriologie et d'archéologie orientale 98:151-78.

Deller, Karlheinz. 1990. Eine Erwägung zur Lokalisierung des aB ON Qabrā/Qabarā. NABU 1990/3:no. 84.

Directorate General of Antiquities. 1979. Atlas of the Archaeological Sites in Iraq. Baghdad: al-Jumhuriya Press.

Eidem, Jesper, and Jørgen Læssøe. 2001. The Shemshara Archives 1: The Letters. Copenhagen: Royal Danish Academy of Sciences and Letters.

Eidem, Jesper, and David Warburton. 1996. In the Land of Nagar: A Survey around Tell Brak. Iraq 58:51-64.

Fiey, J.M. 1965. Assyrie chrétienne: Contribution a l'étude de l'histoire et de la géographie ecclésiastiques et monastiques du nord de l'Iraq. Beirut: Imprimerie catholique.

Fowler, Martin J.F. 2004. Archaeology through the Keyhole: The Serendipity Effect of Aerial Reconnaissance Revisited. Interdisciplinary Science Reviews 29:118-34.

-. 2013. "Declassified Intelligence Satellite Photographs," in Archaeology from Historical Aerial and Satellite Archives. Edited by William S. Hanson and Ioana A. Oltean, pp. 47-66. New York: Springer.

Furlani, Guiseppe. 1934. Gli scavi italiani in Assiria (Campagna del 1933). Giornale della Società Asiatica Italiana 2:265-76.

Geyer, Bernard, and Jean-Yves Monchambert. Editors. 2003. La basse vallée de l'Euphrate syrien du Néolithique à l'avènement de l'Islam: Géographie, archéologie et histoire. Bibliothèque Archéologique et Historique Tome 166. Beirut: Institut Français d'Archéologie du Proche-Orient.

Gibson, McGuire. 1972. The City and Area of Kish. Coconut Grove, Florida: Field Research Projects.

Goblot, Henri. 1979. Les qanats: une technique d'acquisition de l'eau Paris and New York: Mouton.

Gregory, S., and David Kennedy. 1985. Sir Aurel Stein's Limes Report. Oxford: British Archaeological Reports.

Guest, Evan. Editor. 1966. Flora of Iraq, Volume One: Introduction. Baghdad: Ministry of Agriculture.

Ibrahim, Jabir Khalil. 1986. Pre-Islamic Settlement in the Jazirah. Baghdad: State Organization of Antiquities and Heritage, Republic of Iraq.

Ismail, B.K., and A. Cavigneaux. 2003. Dādušas Siegesstele IM 95200 aus Ešnunna: Die Inschrift. Baghdader Mitteilungen 34:129-56.

Jacobsen, Thorkild, and Seton Lloyd. 1935. Sennacherib's Aqueduct at Jerwan. Oriental Institute Publications 24. Chicago: University of Chicago Press.

Jones, Felix. 1855. "Vestiges of Assyria," John Walker.

Jong, Lidewijde de. 2011. Mallowan's Marshes. The archaeology of the Balikh Valley under Roman and Byzantine rule. Zeitschrift für Orient-Archäeologie 4:262-82.

Kennedy, David, and Derrick Riley. 1990. Rome's Desert Frontier from the Air. London: B.T. Batsford.

Layard, Austen Henry. 1853. Discoveries in the Ruins of Nineveh and Babylon; with Travels in Armenia and the Desert. London: John Murray.

Levine, Louis D. 1989. K.4675+: The Zamua Itinerary. State Archives of Assyria Bulletin 3:75-92. 
Lightfoot, Dale R. 2009. Survey of Infiltration Karez in Northern Iraq: History and Current Status of Underground Aqueducts. United Nations Educational, Scientific and Cultural Organization (UNESCO) Report IQ/2009/SC/RP/1: UNESCO.

Lloyd, Seton. 1938. Some Ancient Sites in the Sinjar District. Iraq:123-42.

MacGinnis, John D.A. 2013. Erbil in the Cuneiform Sources. Erbil: Kurdish Regional Government Ministry of Culture and Youth.

Matney, Timothy. 2010. "Material Culture and Identity: Assyrians, Arameans, and the Indigenous Peoples of Iron Age Southeastern Anatolia," in Agency and Identity in the Ancient Near East: New Paths Forward. Edited by Sharon Steadman and Jennifer Ross, pp. 129-47. London: Equinox.

—. 2012. "Northern Mesopotamia," in Blackwell Companion to the Archaeology of the Ancient Near East, vol. I. Edited by Daniel T. Potts, pp. 556-74. Oxford: Blackwell.

Menze, Bjoern H., and Jason A. Ur. 2012. Mapping Patterns of Long-Term Settlement in Northern Mesopotamia at a Large Scale. Proceedings of the National Academy of Sciences 109:E778-E787.

Menze, Bjoern H., Jason A. Ur, and Andrew G. Sherratt. 2006. Detection of Ancient Settlement Mounds: Archaeological Survey Based on the SRTM Terrain Model. Photogrammetric Engineering \& Remote Sensing 72:321-27.

Monchambert, Jean-Yves. 1984. Le futur lac du Moyen Khabour: Rapport sur la prospection archéologique menée en 1983. Syria 61:181-218.

Morandi Bonacossi, Daniele. 2000. "The Syrian Jazireh in the Late Assyrian Period: A View from the Countryside," in Essays on Syria in the Iron Age, Ancient Near Eastern Studies Supplement 7. Edited by Guy Bunnens, pp. 349-96. Leuven: Peeters.

Mühl, Simone. 2010. Durchs wilde Kurdistan: Neue Forschungen in der Provinz Sulaimaniya, Irak. Agora $1: 48-53$

- 2012. "Human Landscape- Site (Trans-) Formation in the Transtigris Area," in Tells: Social and Environmental Space. Edited by Robert Hofmann, Fevzi-Kemal Moetz, and Johannes Müller, pp. 79-92. Bonn: Verlag Dr Rudolf Habelt.

Mühl, Simone, and Burhan S. Sulaiman. 2011. "The Makhul Dam Project," in Between the Cultures: The Central Tigris Region in Mesopotamia from the 3rd to the 1st Millennium BC, Heidelberger Studien zum Alten Orient 14. Edited by Peter Miglus and Simone Mühl, pp. 371-84. Heidelberg: Heidelberger Orientverlag.

Northedge, Alastair. 2005. The Historical Topography of Samarra. Samarra Studies I. London: British School of Archaeology in Iraq.

Nováček, Karel. 2011. Archaeology of the Town under the Citadel Erbil/Hawlér. Subartu 4-5:10-13.

—. in press. "Arbil, Iraqi Kurdistan: The 'Longue Durée' of the City according to New Data," in Proceedings of the 8th International Congress on the Archaeology of the Ancient Near East (8ICAANE), April 30_May 4, 2012 Warsaw. Wiesbaden: Harrassowitz.

Nováček, Karel, Narmin Ali Muhammad Amin, and M Melčák. 2013. A Medieval City within the Assyrian Wall: The Continuity of the Town Arbil in Northern Mesopotamia. Iraq 75.

Nováček, Karel, Tomáš Chabr, David Filipský, Libor Janíček, Karel Pavelka, Petr Š́da, Martin Trefný, and Pavel Vařeka. 2008. Research of the Arbil Citadel, Iraqi Kurdistan, First Season. Památky Archeologické 49:259-302.

Oates, David. 1956. The Roman Frontier in Northern Iraq. The Geographical Journal 122:190-99.

-. 1968. Studies in the Ancient History of Northern Iraq. London: British Academy.

Oates, David, and Joan Oates. 1959. Ain Sinu: A Roman Frontier Post in Northern Iraq. Iraq 21:207-42.

Oded, Bustenay. 1979. Mass Deportations and Deportees in the Neo-Assyrian Empire. Wiesbaden: Ludwig Reichert Verlag.

Parker, Bradley J. 2001. The Mechanics of Empire: The Northern Frontier of Assyria as a Case Study in Imperial Dynamics. Helsinki: Neo-Assyrian Text Corpus Project.

Parpola, Simo. 1995. "The Constructionof Dur-Sharrukin in the Assyrian Royal Correspondence," in Khorsabad, le palais de Sargon II, roi d'Assyrie. Edited by Anne Caubet, pp. 47-77. Paris: Documentation française.

Parpola, Simo, and Michael Porter. 2001. The Helsinki Atlas of the Near East in the Neo-Assyrian Period. Helsinki: Helsinki University Press.

Pedde, Friedhelm. 2012. "The Assyrian Heartland," in A Companion to the Archaeology of the Ancient Near East, vol. II. Edited by Daniel T. Potts, pp. 851-66. Malden and Oxford: Blackwell.

Postgate, J. Nicholas. 1995. "Assyria: The Home Provinces," in Neo-Assyrian Geography, Quaderni di Geografia Storica 5. Edited by Mario Liverani, pp. 1-17. Rome: Università di Roma "La Sapienza".

Radner, Karen. 2006. Provinz. C. Assyrien. Reallexikon der Assyriologie und vorderasiatischen Archäologie $11: 42-68$.

—. 2011. "The Assur-Nineveh-Arbela Triangle: Central Assyria in the Neo-Assyrian Period," in Between the Cultures: The Central Tigris Region in Mesopotamia from the 3rd to the 1st Millennium BC, Heidelberger Studien zum Alten Orient 14. Edited by Peter Miglus and Simone Mühl, pp. 321-29. Heidelberg: Heidelberger Orientverlag.

Reade, Julian. 1968. Tell Taya (1967): Summary Report. Iraq 30:234-64. 
- 1978. Studies in Assyrian Geography, Part I: Sennacherib and the Waters of Nineveh. Revue d'Assyriologie et d'Archéologie Orientale 72:47-72, 157-80.

- 2002. "Shiru Maliktha and the Bandwai Canal System," in Of Pots and Plans: Papers on the Archaeology and History of Mesopotamia and Syria Presented to David Oates in Honour of his 75th Birthday. Edited by Lamia al-Gailani Werr, John Curtis, Harriet Martin, Augusta McMahon, Joan Oates, and Julian Reade, pp. 309-18: Nabu Publications.

Rekavandi, Hamid Omrani, Eberhard W. Sauer, Tony Wilkinson, Esmail Safari Tamak, Roger Ainslie, Majid Mahmoudi, Seren Griffiths, Mohammad Ershadi, Julian Jansen Van Rensburg, Morteza Fattahi, James Ratcliffe, Jebrael Nokandeh, Amin Nazifi, Richard Thomas, Rowena Gale, and Birgitta Hoffmann. 2007. An Imperial Frontier of the Sasanian Empire: Further Fieldwork at the Great Wall of Gorgan. Iran 45:95-136.

Ristvet, Lauren. 2005. Settlement, Economy, and Society in the Tell Leilan Region, Syria, 3000-1000 BC. PhD dissertation, University of Cambridge.

Rouault, Olivier. in press. "In the Heart of Assyria: Qasr Shemamok/Kilizu. A Provincial Capital East of the Tigris. Recent Excavations and New Perspectives," in Proceeedings of the International Congress on the Provincial Archaeology of the Assyrian Empire.

Rouault, Olivier, and Maria Grazia Masetti-Rouault. in press. "Researches in Qasr Shemamok/Kilizu (Iraqi Kurdistan): An Assyrian Town?," in Proceedings of the 8th International Congress on the Archaeology of the Ancient Near East, Warsaw University. Wiesbaden: Harrassowitz.

Safar, Fuad. 1946. Sennacherib's Project for Supplying Arbil with Water. Sumer 2:50-52.

—. 1947. Sennacherib's Project for Supplying Erbil with Water. Sumer 3:23-25.

Scardozzi, Giuseppe. 2011. Multitemporal Satellite Images for Knowledge of the Assyrian Capital Cities and for Monitoring Landscape Transformations in the Upper Course of the Tigris River. International Journal of Geophysics 2011:Article ID 917306.

Stein, Gil J. 2004. "Structural Parameters and Sociocultural Factors in the Economic Organization of North Mesopotamian Urbanism in the Third Millennium BC," in Archaeological Perspectives on Political Economies. Edited by Gary M. Feinman and Linda M. Nicholas, pp. 61-78. Salt Lake City: University of Utah Press.

Stone, Elizabeth C. 2007. "The Mesopotamian Urban Experience," in Settlement and Society: Essays Dedicated to Robert McCormick Adams. Edited by Elizabeth C. Stone, pp. 213-34. Los Angeles: Cotsen Institute of Archaeology.

Ur, Jason A. 2003. CORONA Satellite Photography and Ancient Road Networks: A Northern Mesopotamian Case Study. Antiquity 77:102-15.

- 2005. Sennacherib's Northern Assyrian Canals: New Insights from Satellite Imagery and Aerial Photography. Iraq 67:317-45.

—. 2009. "Emergent Landscapes of Movement in Early Bronze Age Northern Mesopotamia," in Landscapes of Movement: Paths, Trails, and Roads in Anthropological Perspective. Edited by James E. Snead, Clark Erickson, and W. Andrew Darling, pp. 180-203. Philadelphia: University of Pennsylvania Museum Press.

- 2010a. Cycles of Civilization in Northern Mesopotamia, 4400-2000 BC. Journal of Archaeological Research 18:387-431.

—. 2010b. Urbanism and Cultural Landscapes in Northeastern Syria: The Tell Hamoukar Survey, 1999-2001. Oriental Institute Publications 137. Chicago: University of Chicago Oriental Institute.

—. 2013a. "CORONA Satellite Imagery and Ancient Near Eastern Landscapes," in Mapping Archaeological Landscapes from Space: In Observance of the 40th Anniversary of the World Heritage Convention. Edited by Douglas C. Comer and Michael J. Harrower, pp. 19-29. New York: Springer.

—. 2013b. The Morphology of Neo-Assyrian Cities. Subartu 6-7:11-22.

—. in press. "Physical and Cultural Landscapes of Assyria," in Blackwell Companion to Assyria. Edited by Eckart Frahm. Oxford and Malden: Wiley Blackwell.

Ur, Jason A., Philip Karsgaard, and Joan Oates. 2007. Urban Development in the Ancient Near East. Science 317:1188.

- 2011. The Spatial Dimensions of Early Mesopotamian Urbanism: The Tell Brak Suburban Survey, 2003-2006. Iraq 73:1-19.

van Ess, Margarete, Arnulf Hausleiter, Haydar H. Hussein, Nader B. Mohammed, Emmanuele Petiti, and Francelin Tourtet. 2012. Excavations in the City of Arbil, 2009-2011: The Neo-Assyrian Tomb. Zeitschrift für Orient-Archäeologie 5:105-65.

Wilkinson, T. J. 1990. Town and Country in Southeastern Anatolia, Vol. I: Settlement and Land Use at Kurban Höyük and other Sites in the Lower Karababa Basin. Oriental Institute Publications 109. Chicago: Oriental Institute.

Wilkinson, T.J. 1989. Extensive Sherd Scatters and Land-Use Intensity: Some Recent Results. Journal of Field Archaeology 16:31-46.

—. 1993. Linear Hollows in the Jazira, Upper Mesopotamia. Antiquity 67:548-62.

-. 1995. "Late-Assyrian Settlement Geography in Upper Mesopotamia," in Neo-Assyrian Geography, Quaderni di Geografia Storica 5. Edited by Mario Liverani, pp. 139-60. Rome: Università di Roma "La Sapienza". 
-. 2003. Archaeological Landscapes of the Near East. Tucson: University of Arizona Press.

Wilkinson, T.J., and Eleanor Barbanes. 2000. "Settlement Patterns in the Syrian Jazira During the Iron Age," in Essays on Syria in the Iron Age, Ancient Near Eastern Studies Supplement 7. Edited by Guy Bunnens, pp. 397-422. Leuven: Peeters.

Wilkinson, T.J., and D.J. Tucker. 1995. Settlement Development in the North Jazira, Iraq. Warminster: Aris \& Phillips, Ltd.

Wilkinson, T.J., Jason A. Ur, and Jesse Casana. 2004. "From Nucleation to Dispersal: Trends in Settlement Pattern in the Northern Fertile Crescent," in Side-by-Side Survey: Comparative Regional Studies in the Mediterranean World. Edited by John Cherry and Susan Alcock, pp. 198-205. Oxford: Oxbow Books.

Wilkinson, T.J., Eleanor Wilkinson, Jason A. Ur, and Mark Altaweel. 2005. Landscape and Settlement in the Neo-Assyrian Empire. Bulletin of the American Schools of Oriental Research 340:23-56.

Wright, Henry T. 1981. "The Southern Margins of Sumer: Archaeological Survey of the Area of Eridu and Ur," in Heartland of Cities, by Robert McCormick Adams, pp. 295-345. Chicago and London: University of Chicago.

\section{Jason Ur}

Department of Anthropology, Harvard University

11 Divinity Avenue, Cambridge MA 02138 USA

jasonur@fas.harvard.edu

Lidewijde de Jong

Department of Archaeology, Rijksuniversiteit Groningen

Poststraat 6, 9712 ER Groningen, The Netherlands

lidewijde.de.jong@rug.nl

Jessica Giraud

IFPO-Irak-French Consulate in Erbil, Iraq

Valise Diplomatique, 13 rue Louveau, 92438 Chatillon Cedex, France.

James F. Osborne

Department of Near Eastern Studies, Johns Hopkins University

Gilman Hall 117, 3400 North Charles St, Baltimore MD 21218 USA

josbor24@jhu.edu

John MacGinnis

McDonald Institute for Archaeological Research, University of Cambridge

Downing Street, Cambridge CB2 3ER United Kingdom

jm111@cam.ac.uk 
